IZA DP No. 7398

What Did the Old Poor Law Really Accomplish?

A Redux

Avner Greif

Murat Iyigun

May 2013 


\title{
What Did the Old Poor Law Really Accomplish? A Redux
}

\author{
Avner Greif \\ Stanford University \\ Murat Iyigun \\ University of Colorado \\ and IZA
}

Discussion Paper No. 7398

May 2013

IZA
P.O. Box 7240
53072 Bonn
Germany

Phone: +49-228-3894-0

Fax: +49-228-3894-180

E-mail: iza@iza.org

Any opinions expressed here are those of the author(s) and not those of IZA. Research published in this series may include views on policy, but the institute itself takes no institutional policy positions. The IZA research network is committed to the IZA Guiding Principles of Research Integrity.

The Institute for the Study of Labor (IZA) in Bonn is a local and virtual international research center and a place of communication between science, politics and business. IZA is an independent nonprofit organization supported by Deutsche Post Foundation. The center is associated with the University of Bonn and offers a stimulating research environment through its international network, workshops and conferences, data service, project support, research visits and doctoral program. IZA engages in (i) original and internationally competitive research in all fields of labor economics, (ii) development of policy concepts, and (iii) dissemination of research results and concepts to the interested public.

IZA Discussion Papers often represent preliminary work and are circulated to encourage discussion. Citation of such a paper should account for its provisional character. A revised version may be available directly from the author. 


\begin{abstract}

\section{What Did the Old Poor Law Really Accomplish? A Redux*}

This paper examines the evolving effects of England's Old Poor Law (1601-1834). It establishes that poor relief reduced social unrest from around the late-17th century through the turn of the 19th century, at which point it began to spur population growth and its social stability effects dissipated. These conclusions are based on a new dataset encompassing 39 English counties from 1650 to 1815. It includes observations on the amount of poor relief offered, occurrences of food riots and other types of social unrest, population growth and a host of other variables. The paper first documents that county-level variations in poor relief had a statistically significant and quantitatively meaningful non-monotonic impact on population growth. Aid to the poor reduced population growth through the 1780 s or 1820 s when it began to exert significantly positive effects. Moreover, the Old Poor Law reduced food riots in the late-17th century and through most of the 18th century, but this effect dissipated in the early 19th century when poor relief began to generate population growth. Our analyses, thus, establish that the Old Poor Law fostered social order and stability for more than a century after which the Malthusian income effects dominated.
\end{abstract}

JEL Classification: N0, N33, O10

Keywords: $\quad$ social institutions, Malthus, social stability, economic development

Corresponding author:

Avner Greif

Department of Economics

Stanford University

Stanford, CA 94305

USA

E-mail: avner@stanford.edu

\footnotetext{
* This paper benefitted from comments by Ran Abramitzky, Lee Alston, Jennifer Bair, Carew Boulding, Paul David, Emanuele Felice, Joe Jupille, Wolfgang Keller, Craig Mclntosh, Gavin Wright and participants in seminars at Stanford, Berkeley, the IBS Politics \& Institutions workshop at the University of Colorado, Southern Methodist University, Universidad Torcuato di Tella, the 2011 IEA Meetings in Beijing, and the 2013 AEA Meetings in San Diego. Avner Greif thanks the Canadian Institute for Advanced Research (CIFAR) for support.
} 


\section{Introduction}

The enactment of the Old Poor Law (43 Eliz.1 c 2) in England in 1601 is a watershed in the evolution of social institutions in the Western world. Although tax-based poor relief was extended in England before, the Poor Law Act formalized, for the first time in history, a public system of poor relief financed by a special tax and under which the destitute had a legal 'right' for support. Each English parish was authorized and obligated to levy a tax to care for its poor. ${ }^{1}$

By the early 19th century, the Old Poor Law came under scrutiny and its critics emphasized its adverse effect on population growth. Thomas Malthus is perhaps the best known and influential critic. In the words of Boyer (1990, p. 151), Malthus argued that "the Poor Law undermined the 'preventive check' to population growth" (late marriage and abstention) by artificially reducing the cost of having children. Under the system of child allowances, there was no reason for laborers "to put any sort of restraint upon their inclinations, or exercise any degree of prudence in the affairs of marriage, because the parish is bound to provide for all who are born' (1817: II, 371). "[It thus affords] a direct, constant, and systematic encouragement to marriage" (1817: II, 138). Malthus concluded that, in the long run, poor relief would create an excess supply of labor and thus, ironically, "increase the poverty and distress of the labouring classes of society" (1817: II, 371)."

Malthus thus argued that the Poor Law depressed living conditions and that it was selfdefeating. Early empirical studies disputed this claim. Huzel (1969, 1980), for instance, claimed that child allowances paid under the Old Poor Law had no Malthusian population effects. Later empirical analyses, however, vindicated Malthus. The definitive analysis evaluating the role of aid on population growth was furnished by Boyer (1989) who used a cross-sectional, parish-level estimates covering the years between 1826 and 1830. His analysis identified empirical support for the Malthusian channel.

Some of Malthus' contemporaries, however, emphasized that the Poor Law might be crucial to sustain social order and, thus, promote growth and relieve population pressures. In fact, even earlier concerns with social order was an important consideration in extending aid to the poor through redistributive public policies. ${ }^{2}$ In 1683, Sir Matthew Hale, a late Lord Chief Justice of the Kings Bench, expressed this concern in a book discussing the "provision for the poor." Providing for the poor, he noted, "is an act of great Civil Prudence and Political Wisdom: for Poverty in itself is apt to emasculate the minds of men, or at least it makes men tumultuous and unquiet. Where there are many very Poor,

\footnotetext{
${ }^{1}$ Slack (1988) reviews the evolving motivation for poor relief and King (2000, chapter 1) reviews the legal framework of the poor law.

${ }^{2}$ Thus, for example, Blaug $(1963,1964)$ argued that the Poor Law was a means to deal with structural unemployment in a declining agricultural sector. Solar (1995) discussed its impact on economic development.
} 
the Rich cannot long or safely continue to be wealthy" (p. 30). ${ }^{3}$

By the end of the 18th century, proponents of the poor law explicitly recognized the link between poor support and social order when economic changes produced socially risky labor displacement. Economic changes, they argued, increased poverty risk, which, in the absence of appropriate relief, could lead to social unrest. In 1797, for example, Sir Frederick Morton Eden, the 2nd Baronet of Maryland and a pioneering social investigator wrote that "by some persons in this country... the recent introduction of machines into the woollen manufacture ... is a great national misfortune, that a wool-spinner can, by means of machines, do ten times the work he could perform without them" (vol. III, p. 874). Poor relief can be used so that "[the] inconvenience [of technical change] to individuals will be softened and mitigated, indeed, as far as it is practical" (ibid). In fact, "almost every new form of machinery [in the woolen industry] ... was met with anger in the form of riots" (Archer, 2000, p. 45). Concurring with the Industrial Revolution, the 18th century "witnessed an extraordinary rise in the extent and frequency of food riots" (Outhwaite, 1991, p. 41).

Despite this history, the economic literature has been wholly silent on the link between poor relief and social order. Moreover, by testing the Malthusian channel only over a relatively short period of time between 1826 and 1830, it fell short of evaluating the fuller and longer-term effects of the Old Poor Law on population growth. For example, it could have well been the case that poor relief reduced fertility in the 17th and 18th centuries. Such a reduction might have reflected, in turn, that relief provided an alternative to children as a source for support in times of need.

Accordingly, this paper presents a dynamic and comprehensive analysis of the effects of the Old Poor Law on both population growth and social order. The analysis is 'dynamic' in that it explores the influence of the Old Poor Law over the long run, covering more than a century and a half, and allowing this influence to change over time. The analysis is 'comprehensive' in that it examines the role of the Old Poor Law in both population and social order dynamics using data from all English counties.

To this end, we assemble a panel covering 39 counties between the years of 1650 and 1830. The data include information on the amount of public resources available for poor relief within the English counties observed at six different points in time (1685, 1750, $1776,1784,1803,1815)$. We combine these data with a variety of measures of population growth and social instability observed within each county over previous and subsequent periods of time. We then control for a host of county-specific but time-variant data, such as regional indicators, levels of population, wealth and tax-base indicators as well as the

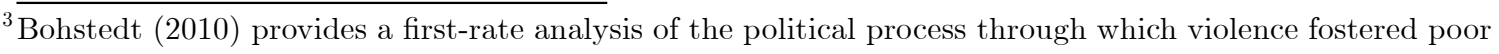
relief. 
extent to which the local economies were market dependent.

Our analysis first documents that county-level variations in aid to the poor had a statistically significant and quantitatively meaningful non-monotonic impact on population growth. Depending on the exact empirical specification and controls employed, aid to the poor reduced population growth through the 1780 s or 1820 s when it began to exert significantly positive effects. Throughout the same period, however, county-level variations in the amount of poor relief had a negative and statistically significantly impact on the propensity of food riots within each county in England. In effect, we substantiate that the Old Poor Law was particularly good at subduing social unrest in England in an era in which rapid technological advances were displacing labor at ever higher rates. Indeed, as we shall elaborate more in Section 2 below, England's transition from an agricultural to a manufacturing economy was relatively more peaceful than those of continental Europe countries and elsewhere.

Our empirical results are consistently strong, statistically significant and robust to a variety of alternative estimation methods and the inclusion of a host of explanatory controls. In addition, we verify the validity of these results with IV estimates according to which poor relief by county is instrumented with the amount of usable land and the rates of population loss within the county due to the Black Plague in the late-14th century. The predicted poor relief expenditures then generate statistically significant net negative effects on food riots and population growth throughout the 17th and 18th centuries which turn positive and significant afterwards.

The finding that the same social institution had multiple effects and its impact involved nonlinearity over time is methodologically important. In evaluating historical institutions, the data are often biased in favor of later periods and specific implications. Extrapolating results based on such data regarding the impact of the institutions in question in different periods, therefore, needs to be done with care (Greif, 2006). Similarly, the important implication of an economic institution may not the observable economic outcomes its intended impact, such as poverty alleviation in the case of the Old Poor Law. Rather, its important role may be in its unexpected consequences such as social order and technological innovations (Greif, Iyigun, and Sasson 2011, 2012).

The rest of our paper is organized as follows: The next section discusses the historiography of poor relief in England and sets the stage for our empirical study. Section 3 describes our data sources and the summary statistics of our key variables. Section 4 presents a host of baseline estimates of the links between poor relief and population growth. The subsequent section then turns to an investigation of the effects of aid to the poor on social unrest as measured by food riots and social disturbances related to food supply. Section 6 concludes. 


\section{The Historical Context}

The working people of pre-modern England were aware of poverty risk as evident in the proliferation of mutual insurance organizations. In the early 16th century, the majority of England's rural and urban populations belonged to fraternities and guilds that provided social safety nets (Richardson, 2005). Friendly Societies were later common. In 18th century Yorkshire county, 15 parishes had at least 144 societies with 5,737 members implying one member per every four households (calculated from Eden, 1797, vol. 3, pp. 811-890). Members included "almost every manufacturer" (ibid, p. 874) in the parish of Wakefield, "several shop-keepers, and respectable trade-men," in Surrey-Epson (ibid, pp. 697-700). More generally, skilled workers, such as bakers, carpenters, tailors, butchers, watchmakers, white-smiths, and paper-makers, comprised the memberships. In 1801, about 40 percent of England's households were members of a friendly society. ${ }^{4}$

Fear of poverty and destitution also manifested itself as the main source of social unrest in England during its transition to the first modern economy. The four largest rebellions under the Tudor, and the only ones with more than 10,000 participants, were wholly or partially in response to threats to peoples' livelihood. ${ }^{5}$ More generally, economic issues were the main source of social disorder in England during that period and were concerning labor disputes, fear of losing sources of livelihood, and food prices. Specifically, social disorder was mainly caused by economic concerns involving labor-saving machinery, food prices, wages, and enclosures. About 53 percent (54 out of a total of 101) of the significant riots and protests from 1770 to 1806 fell in this category. The three largest sub-categories were food riots (21), labor related disorder (13), and resistance to new technology (13). ${ }^{6}$

Violence motivated by economic desperation was perceived by contemporaries as a threat to social order. "Vagrancy was one of the most pressing problems of the Tudor and early Stuart" (Beier 1985, p. xix). Such a perception is expressed, for example, by Sir Matthew Hale, the Lord Chief Justice of the Kings Bench who, as noted above, published a book concerning poverty in 1683. Hale recommended to invest heavily in eradicating poverty because it undermined "public wealth, and peace" (p. 7) as the poor engaged in "thieving and stealing, ... cutting and destroying of woods, pulling of hedges, and [trespassing] to corn" (p. 58-9). An earlier student of poverty, writing in 1646 estimated that although there were only "80,000 idle vagrants" they "prey upon the commonwealth" thereby causing great damage. Specifically, in addition to a yearly maintenance cost of $£ 88,740.12$ s.6d they also cause $£ 365,000$ in damages (cited in Eden, 1797, vol. 1, p. 167).

\footnotetext{
${ }^{4}$ There were about 1.7 million families in England's counties around 1801 and 674,000 members in Friendly Societies in 1803 (1801 Abstract, vol. 1, summary and 1804 Abstract, p. 714).

${ }^{5}$ These four riots were the Cornish revolt of 1497, Kett's Rebellion in 1549, the Pilgrimage of Grace, and the Lincolnshire rising in 1536.

${ }^{6}$ The data are available upon request. Also see below for the discussion of the data in Bohstedt (2010)
} 
Taken together, these sums amounted to about 50 percent of the king's revenue from direct and indirect taxes in $1640 .^{7}$

While economic changes can undermine social order, economically-beneficial innovations can often produce negative pecuniary externalities and those affected by others' innovations might respond violently particularly in poor unequal societies in which people live on the margin of subsistence. Expectations of violent responses could, in turn, reduce the return to innovations thereby can discourage even socially beneficial economic changes. Social institutions can thus facilitate economic progress by reducing the likelihood of violent responses from those who would be negatively effected.

Whereas the interplay between economic change and social instability was recognized fairly early on, the links between poor relief and socially beneficial economic change seem to have penetrated public discourse only by the end of the 18th century. In his aforementioned book, Sir F.M. Eden explicitly recognized the trade-offs between poor relief and socially beneficial economic changes. He argued that enclosures, "manufactures and commerce are the true parents of our national Poor" (vol. 1, p. 60-1). Moreover, "any ... machines or contrivances calculated to lessen labour ... throw many industrious individuals out of work; and thus create distresses that are sometimes exceedingly calamitous. Still,... [they] promote the general wealth, by raising the largest quantity of provisions, or materials for manufacture" (ibid, p. xiv). Poor relief can be used so that "their inconvenience to individuals will be softened and mitigated, indeed, as far as it is practical" (ibid). The alternative is stagnation. Relief should "by no means ... counteract any new plans of improvement, ... If this were not the proper line to pursue, it must be confessed, the Turks alone are right, in not suffering a printing-press to be introduced into their dominions, merely because one of it's immediate-effects would be, the depriving many thousands of unoffending, industrious, hackney writers, of their usual means of earning a livelihood" (ibid).

As far as the evolution of aid to the poor in England is concerned, secular and religious organizations - monasteries, fraternities, mutual-insurance guilds, and communesprovided assistance in times of need prior to the 16th century (e.g. Reynolds, 1984; Brenner, 1987; Archer, 1991). They provided, for example, poor relief and insurance in cases of temporary unemployment and disability. In the early 16 th century, the majority of the commoners in England belonged to fraternities and guilds that provided social safety nets (Richardson, 2005). Getting relief from these risk-sharing institutions was, however, uncertain as they were either provided by charity organizations (e.g., by the Church) or cooperatively financed by working people without much wealth.

Population growth and urbanization during the 16th century pressured this system of

${ }^{7} \overline{\text { Data by P. K. O'Brien and P. A. Hunt at http://esfdb.websites.bta.com/table.aspx?resourceid=11686. }}$ 
poor relief. Matters got worse when, during the Wars of Religion, rulers confiscated the property of many welfare-providing organizations. In England, Henry VIII dissolved the monasteries in 1536-40 and shut down all religious guilds, fraternities, almshouses, and hospitals in 1545-49. These actions "destroyed much of the institutional fabric which had provided charity for the poor in the past" (Slack, 1990, p. 8).

The lack of an effective poor relief system and population growth then began to pressure wages and increased poverty. States responded by demanding local administrative bodies, such as parishes and cities to support the needy. In England, the first tax to support the poor was introduced in 1572 but the Poor Law Act of 1601 (the Old Poor Law) formalized the system which lasted, with some modifications, until 1834. Each parish was authorized and obliged to levy a property tax to care for the poor (Boyer, 1990).

Private relief remained important in England and was encouraged by the state. The Statute of Charitable Uses (1601) protected charitable gifts from misuse. Moreover, a 1597 law holding parents and children responsible for each others' support was extended, in 1601, to include grandparents and grandchildren. Thus, relatives, friends, charity organizations, and Friendly Societies were important sources of support (e.g., Dyson, 2009; Ben-Amos, 2008). Yet, 1601 marked the beginning of an era in which the state was a major provider of poor relief.

Annual public spending on poor relief financed through taxes in England was significantly large until the early-19th century. As a share in the GDP, poor relief was about .7 percent of GDP in 1750 and rose to 1.7 percent in 1803. In both years, relief was about 2.2 percent of total income and substantially increased the income of the working poor. In 1685-8, relief equals 10 percent of the income of the bottom 50 percent of households and 31 percent of the bottom 25percent of households. Similarly, in 1803 poor relief was 8.9 percent of the income of the bottom 50 percent of households and 31.8 percent of the bottom 30 percent. $^{8}$

Poor relief expenditures were also large compared to other public expenditures (Hartwell 1981). To illustrate, in 1788, a peace time year for which we have particularly good data, the military expenditures of Great Britain (England, Wales, and Scotland) amounted to $£ 3,822,500$ (for the Army, Navy, Militia and Ordinance) and civil expenditure by the national government (excluding interest) was $£ 3,846,474 .^{9}$ Public expenditures on the poor by local authorities were $£ 1,530,000,{ }^{10}$ and private donors contributed more than $£ 250,000{ }^{11}$ Expenditures on the poor were, thus, roughly about 50 percent of those

\footnotetext{
${ }^{8}$ Sources: Broadberry, Campbell, Klein, Overton and van Leeuwen (2011) for GDP; Branko, Lindert and Williamson (2007) for incomes; Eden (1797, vol. 1, pp. 228, 230) and Abstract of Returns (1804, p. 714) for poor relief.

${ }^{9}$ Lowndes and Debrett 1789, Part I.

${ }^{10}$ In 1776, Boyer, EH.net, table 1 and see our data for that year.

${ }^{11}$ Abstract of the return of charitable donations, 1816 page iv.
} 
devoted to either military expenditure or all other civil expenditures.

Shifting the responsibility for poor relief to the state (via local administrators) was a European phenomenon and publicly organized poor relief systems were established elsewhere (Geremek, 1997; de Vries and de Woude, 1997, pp. 654-664). Yet, the English Old Poor Law system was more reliable and generous than the continental ones. In England, expenses were financed through a variable poor rate on the assessed rental value of local real estate property and most aid was given without forcing the recipient to move to the poor house. ${ }^{12}$ Continental poor relief, by contrast, was financed through a variety of sources: voluntary donations, capital income, subsidies from local and national governments, and general tax revenues. Funding was, therefore, less reliable. Furthermore, the legal right to relief was well defined in England while rights were vaguely defined, less credibly assured, and generally at the discretion of local authorities on the continent.

In any case, expenditure per capita in England were exceptionally high; 7.5 times higher than in France in the 1780s, 2.5 times higher than in the Netherlands in the 1820s, and 5 times higher than in Belgium in the 1820s. ${ }^{13}$ England's exceptionality reflects distinct needs in the late 16th century when these systems were created. While peasantry and other 'customary' labor relations that insured the poor still dominated in other European states, the transition to wage laborer had already begun in England and private donations to charity. ${ }^{14}$

In addition to being large, poor relief in England was increasing until the early 19th century. Expenditures were about $£ 600,000$ in $1677, £ 665,000$ in $1685, £ 819,000$ in $1698, £ 1,000,000$ around $1710, £ 689,971$ in $1751, £ 1,521,732$ in $1776, £ 1,912,241$ in 1784 , $£ 4,077,891$ in 1803 , and $£ 7,890.148$ in 1817 . $^{15}$

By the late 18th century, the authorities and the public became concerned that this trend was unsustainable. The view of the Committee on the Poor Laws from 1817 is representative: "A compulsory contribution for the indigent, from the funds originally accumulated from the labour and industry of others, could not fail in process of time, with the increase of population which it was calculated to foster, to produce the unfortunate effect of abating those exertions on the part of the labouring classes" (p. 4).

A new poor law replaced the old one in 1834 with the objective "to raise the labouring

\footnotetext{
${ }^{12}$ Those who financed the Poor Law had no legal rights to influence risk taking. Moreover, farmers who took risks (by specializing in grains) had the political power to transfer the cost of insurance on to others (Boyer, 1990).

${ }^{13}$ Boyer (1990), Mokyr (2002) and Kelly and Ógrada (2008).

${ }^{14} \mathrm{On}$ these and other aspects of the system see, for example, Boyer (1990); Slack (1990); Solar (1995); Kelly and Ógrada (2008). Patriquin (2006) compares the English case with those of Scotland and Ireland. Lindert (2004) is the seminal work in economic history on public goods.

${ }^{15}$ Data up to and including 1751 are from Colquhoun (1806, p. 36) and those for later years are from the Committee on Poor Rate Returns (1821-26, vol. 2, Appendix A). Various sources provide slightly different amounts, but basically paint the same picture.
} 
classes ... from the idleness, improvidence, and degradation, into which the ill administration of the laws for their relief has thrust them and immediately arrest the progress, and ultimately to diminish the amount of the pressure [tax] on the owners of lands and houses " (Pratt 1834, p. v). The new law facilitated labor mobility and increased the non-pecuniary cost of getting assistance. It reduced poor relief and as late as 1853 the expenditures were lower in absolute and per-capita terms than in 1834 despite population growth (Poor Law Board, 1853, p. 4). The percentage of the population getting poor relief declined from 11.4 percent in 1803 to 2.4 percent in $1901 .^{16}$

When enacted, the Poor Law improved welfare. The elasticity of mortality with respect to real wages was negative and statistically significant from 1540 to 1640 but it was basically zero from 1640 to $1740 .{ }^{17}$ The improvement was due to better poor relief, and not higher real wages, reduced variance of grain output, increased urbanization, or changing climate (Kelly and Ógrada, 2008). Mortality rates of the non-elite declined (ibid) and better nutrition, to which the Poor Law contributed, "should be regarded as one in a battery of factors, often interacting, which played a key rule in Britain's mortality transition" (Harris, 2004, p. 380). ${ }^{18}$

To sum: Social institutions can alleviate the risk of violent responses to redistributive economic, social and demographic changes. In the case of English transition to a modern economy, there was relatively little popular resistance to major economic transformations such as the decline in the putting-out system, the introduction of hourly wage, or the New Husbandry. England was remarkably peaceful during its transition. As Solar (1995) noted, for example, "while there was some resistance to enclosure, the English were, by continental or Irish standards, quite easily separated from the land in the seventeenth and eighteenth centuries" (p. 9).

Did the Old Poor Law contribute to this outcome? Or was it primarily responsible for undermining the "preventive" Malthusian check? We empirically investigate these questions next.

${ }^{16} \overline{\text { Oficial statistics. See Boyer on EH.net and }}$ the additional estimates presented there.

${ }^{17}$ Nicolini (2007); information from Parish's registers is available from 1540. See Landers (1987) about London.

${ }^{18}$ The role of better nutrition in the decline in morality has been particularly emphasized by McKeown and his co-author and surveyed in Harris (2004). Smith (2008) emphasizes the positive role of the Poor Law in reducing the risk of labor migration. 


\section{The Data}

\subsection{Data Sources}

To investigate the role of aid to the poor on population growth and social stability, we gathered a panel data covering 39 English counties over the period between 1650 and 1830 CE.

We have variations for England's 39 counties in both the amount of poor relief offered, rates of population growth as well as the documentation of food riots and other types of social unrest, such as land and enclosure protests as well as clubmen and militia protests. ${ }^{19}$ These social disturbance data are culled from Bohstedt (2010) and Charlesworth (1983). For county population levels and rates of growth, we rely on the 1801 and 1811 population censuses, and the 1824 Report of the Committee on Poor Relief. The sources of our other control variables are: for county wealth measures, Buckatzsch (1950) based on tax assessments by the state; for wheat prices, Clark (2003); for market dependence measures, Kussmaul (1989) and the Parish Register Abstracts in the Censuses of 1801, 1811, and 1821; and for land protests and clubmen and militia uprisings, Charlesworth (1983). A list of the main variables, definitions and sources for our dataset is in the appendix at the end.

\subsection{Descriptive \& Summary Statistics}

Table 1.A presents the descriptive and summary statistics of our dataset. Due to data limitations, this is an unbalanced panel covering a total of 273 observations as an upper bound. And depending on the estimation and controls involved, the number of observations range from 191 to 233 in each of our baseline regressions.

In fact, the first poor relief data across the English counties are available at six points in time: the first observations are from 1685, and the rest are from 1750, 1776, 1784, 1803 and $1815 .^{20}$ Our primary social disorder data are a variety of food riots because the latter are documented for England in fairly high detail for the years between the 1650s and the 1830s. Given this imbalance between our poor relief data and social unrest, we observe poor relief in the years that are available to us, followed by the frequency of food riots in the subsequent windows of time. For instance, we observe poor relief differences in 1685 and assess their impact on food riots and population growth in the period from 1686 to 1749. In similar fashion, we then relate county-level resources available for poor relief in

\footnotetext{
${ }^{19}$ We consistently aggregated the data for York and included London in Middlesex.

${ }^{20}$ To be more precise, the 1784 data are averaged using the three consecutive years of 1783,1784 and 1785 , although, depending on the variable in question, they may come from one or two of those years only. Poor law years end at Easter.
} 
$1750,1776,1785,1803$ and 1815 to the frequency of food riots and population growth alternatively that occurred in each county in the five additional intervals of time covering 1751 to 1775,1777 to 1783,1785 to 1802,1804 to 1814 , and 1816 to $1830 .^{21}$ On this basis, we are able to estimate the role of poor relief on social unrest as well as population growth using a panel of 39 English counties, covering six intervals of time. ${ }^{22}$

To derive our population growth rates, we relied on population data in the official records from 1700, 1750, 1801 and 1811. The population levels for our five other main dates $(1650,1685,1750,1776,1784)$ were interpolated from the data for the bracketing official dates. Based on these population levels, we then computed annualized growth rates for each of the six time intervals in our panel.

The measure we use for resources available for aid to the poor is the total amount of tax assessed and raised at the county level for the finance of local expenditures. Only part of this amount was spent on poor relief. For two years only (1685 and 1750), the data available are actual expenditures on poor relief. In general, the fact that our explanatory variable is the hypothetical upper bound for the capacity of counties to supply poor relief, it provides an exogenous source of variation across the counties and over time that should enable us to identify the causal impact of aid to the poor on food riots. The poor were also supported by organized charities, private donations and Friendly societies, but systematic data, to the best of our knowledge, do not exist. ${ }^{23}$

In terms of some of the controls we employ, such our wealth proxies, data were scarcer than our poor relief and riots data. Thus, we had to interpolate some of these controls in a variety of ways. For our Wealth variable, for example, we interpolated from the taxassessment relative wealth measures produced by Buckatzsch (1950, Table 1), available for the years of $1649,1672,1693$, and 1803. The market dependency measure we use is based on the population share not employed in agriculture. For our market dependency data in 1784, 1802 and 1815, we calculated this share from the population censuses of 1801, 1812 and 1821. For the other periods, we used Kussmaul (1989) data on proportions of agricultural parishes in a county. Grain prices are from Clark (2003) and they are averaged on an annualized basis following the same procedure we employed for riots. Finally, note that Black Death Impact is a time invariant, county-level control variable measuring the difference in the county population estimates between 1290 and 1379, thereby proxying

${ }^{21}$ Due to the fact that our second panel period covers a much longer time interval than the period that precedes it or those that follow, we have experimented with a couple of other narrowers windows of aggregation for food riots over the period between 1686 and 1749 . Our results were generally robust to the choice of aggregation during this time period. We elaborate more on this point below.

${ }^{22}$ We are able to rely on six time periods even when we include the lagged dependent variable for food riots because, although we do not have poor relief data from a date earlier than 1685, we were able to compile observations on food riots for the period between 1651 and 1684 .

${ }^{23}$ Data for London is included in Middlesex county and Yorkshire county is considered one county throughout. 
for the impact of the Black Death plague on the counties.

As shown in Table 1.A, the total amount of public resources available for poor relief comes out to slightly under 79 thousand pounds per year, per county. ${ }^{24}$ In per capita, county population terms, this comes out to an average of 374 pounds of poor relief per annum, per county. As listed in the third row of the table, we have an average of 4.31 riots per period, per county, although once we normalize these riots by the differences in the number of years in our windows of observation, we have .779 food riots per annum over each of the six periods in which we observe riots. The population data are also in thousands. Each county had roughly 180 thousand people on average, although there was a fairly large variance in this with Middlesex (encompassing London) having in excess of a million people on average over the seven periods of time in our data. The next row of Table 1.A shows that population growth rates ranged from a low of negative half a percent to 1.7 percent per annum, with an average population growth rate of roughly half a percent per county per year.

The two panels of Table 1.B present the correlation matrices. Here, we see that riotsboth in total and per annum terms - are all slightly negatively correlated with poor relief resources in total and in per-capita terms. There were more total riots in more populous and market dependent counties and slightly more riots in poorer counties. Riots were slightly more common in the southern counties than they were in northern counties, while both poor relief resources and riot frequencies were increasing over time. ${ }^{25}$ In the lower panel of this table, we also see that poor relief is very positively correlated with law enforcement expenditures and food prices (as proxied with wheat prices), while no strong correlation can be gleaned between riots and food prices or between the former and law enforcement expenditures. Finally, in step with the Malthusian population to wage and income dynamics, we can see in the penultimate row of Table 1.B that there tended to be more riots (both in total and per annum terms) in counties that suffered less deaths from the Black Death in the 14th century.

[Tables 1.A and 1.B about here.]

\footnotetext{
${ }^{24}$ The poor relief data shown here are in thousands of British pounds expressed in nominal values. An alternative series of poor relief data are exressed in real terms, although our main results are qualitatively similar when we use real and nominal amounts of poor relief.

${ }^{25}$ Our region code progressively increases, going from 1 for northern counties to 2 for counties in mid-England and to 3 for southern English counties.
} 


\section{Aid to the Poor \& Population Growth}

\subsection{Baseline Estimates}

We begin our empirical analysis with some baseline Ordinary Least Square (OLS) estimates of population growth. In Table 2, we present six regressions that all cluster errors by county. All regressions include time trends and county population levels as the most parsimonious set of controls. Furthermore, we include region fixed effects in the second and fifth estimates and county fixed effects in the third and sixth specifications. And while the first three columns present the simplest specifications with a minimal number of explanatory variables, the last three columns list regressions that control for more county-specific as well as time-and-county-specific controls.

These results strongly validate Boyer's (1989) findings: County-level variations in aid to the poor per capita exerts positive and, in five out of six regressions, statistically significant effects on population growth. The main difference, of course, is that these estimates suggest that the Malthusian population dynamics were operative even in the very long run spanning 1650 to 1815. In terms of the other controls included in the final three columns, food price variations (as proxied by Wheat Price) also reveal Malthusian income effects. However, wealthier counties experienced slower population growth rates, contradicting, at least on face value, the Malthusian effects of food prices on population growth rates. Along the same lines, Black Death Impact exhibits positive and significant coefficients in both regressions it is included, reflecting the fact that those counties that suffered the highest death tolls due to the Black Death showed slower rates of population growth. This, too, seems to contradict the Malthusian prediction that population growth rates should have rebounded faster in counties where the impact of the Black Death was most severe. It is possible that both of these findings might be, at least in part, due to the fact that we include Market Dependency as an additional control with more marketdependent counties experiencing, ceteris paribus, faster population growth. Nevertheless, the key point here is that the inclusion or exclusion of a host of additional controls does not come to bear on the statistically significant and positive effects of Poor Relief per Capita on Population Growth.

[Table 2 about here.]

Our panel includes a very long time-dimension, covering a 166-year time interval. Moreover, given that existing work on the impact of the Old Poor Law on population growth concentrated on very short time periods covering the $1820 \mathrm{~s}$, a natural question to ask is whether or not poor relief came to bear on population growth monotonically (and almost linearly) over the long run too. Table 3 provides the answer to this key question. 
It does so by including the same six regressions shown in our previous table, but this time also including the interaction of Poor Relief per Capita with Year as an additional explanatory variable.

The estimates now unambiguously show a non-monotonic effect of aid to the poor on population growth in the long run. In five of the six regressions, we have statistically significant and negative direct effects of Poor Relief per Capita, combined with positive and significant effects conditional on Year. On this basis, we find that the net effect of poor relief on population growth was initially negative and turned (potentially) positive later in time. Taking the statistically significant effects shown in the first five columns, we can calculate the year in which the net effect of aid to the poor on population growth turned positive. In turn, we find threshold dates that are 1805, 1801, 1784, 1781 and 1774, respectively.

The quantitative magnitude of the impact of poor relief on population growth is also very large: Taking for instance, the estimates in column (5), we see that a one standard deviation higher amount of poor relief per capita would have generated three-tenths of one percent drop in population growth in 1700 , whereas an identical amount of additional poor relief would have raised population growth by four-tenths of one percent in $1815 .{ }^{26}$ Given that average population growth equals slightly in excess of five-tenths of one percent over the whole sample, these figures represent sixty percent lower and eighty percent higher rates of population growth due to one standard deviation higher level of poor aid per capita, respectively. In terms of other controls employed in the final three columns, we get estimates that are very much in line with those reported in Table 2.

[Table 3 about here.]

\subsection{Alternative Specifications \& Robustness}

The results we report above are very strong and highly robust to differences in empirical specification, explanatory controls utilized and alternative definitions of aid to the poor, for example. In what follows, we discuss some alternative estimates we considered.

In Table 4, we consider an alternative dependent variable, this time regressing the natural log of population growth (plus one) on the standard sets of explanatory variables we employed in Table 3. As shown, all results are very much in agreement with those we reported earlier.

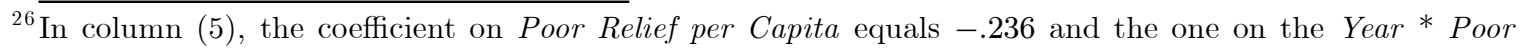
Relief per Capita equals .000133. The standard deviation of Poor Relief per Capita equals .293, as shown in Table 1.A. Hence, in the year 1700 , the net effect comes out to $.293 *(.000133 * 1700-.236)=-.003$. And, in 1815 , it nets out to $.293 *(.000133 * 1815-.236)=.004$. 
[Table 4 about here.]

A primary concern involving our main explanatory variable, Poor Relief per Capita, is that it implicitly reflects the impact of population growth in its denominator and, thus, is somewhat contaminated by the left-hand-side variable.

Furthermore, the so called Settlement Laws might give the impression that the poor could not respond to poor relief in the parish of their residency. The Settlement Act of 1662 allowed relief only to the poor who had the right of residency in the parish due to birth, marriage, or apprenticeship. Parishes had the to right to extradite the non-resident poor to their parish of settlement. This law was put into effect and the Abstract of Answers and Returns of 1804, for example, reveals (pp. 714-5) that for the year ending at Easter 1803 expenditures on the removal of non-residents poor and other administrative costs were about 4.5 percent of the total spent on poor relief. At the same time, support of non-parishioners was common. In fact, in 1803, the share of the poor on financial support who were non-parishoners amounted more than 16 percent of all adults and children who were supported. And this figure excludes greater London where the share of such aid recipients was more than twice as high.

While Poor Relief per Capita might be exposed to endogeneity issues, the total amount of public resources available for aid to the poor, which is the numerator of Poor Relief per Capita, is more immune to this problem, as it represents the local level government revenues collected net of collection costs. Specifically, it is the amount assessed and collected by the local authorities using a 'rate' imposed on the assessed value of property in that locality. Although the law allowed imposing this rate on (real or personal) productive property of any kind, the rate was de facto imposed, by and large, during this period on real estate.

As a remedy, we ran regressions analogous to those in Tables 3 and 4, but this time with Poor Relief as our key explanatory variable. The results we get here are also very strong and in line with those we generated using Poor Relief per Capita as our main explanatory variable.

Wheat Price once again shows some Malthusian income effects and, unlike our earlier estimates, Usable Land also produces positive population effects in accordance with Malthusian dynamics. Turning to the threshold time period around which the population impact of aid to the poor went from negative to positive, we find dates that range within a remarkably narrow range of 1787 to $1813 .{ }^{27}$ And, once again, the estimated population

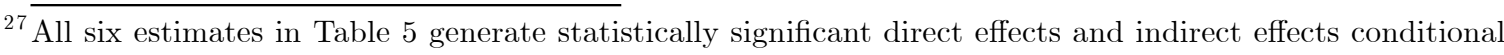
on time. Taking the coefficients on Poor Relief and Year * Poor Relief, respectively we get the dates 1805, $1804,1802,1813,1810$, and 1787 as turning points for the net effect of poor relief on population growth turning positive.
} 
effects are quantitatively very large: As an illustration, the figures in column (6) imply that a one standard deviation higher amount of poor relief in aggregate would have generated more than three-tenths of one percent drop in population growth in 1700, whereas an identical amount of additional poor relief would have raised population growth by onetenths of one percent in $1815 .^{28}$ Taken together with the average population growth that equals slightly in excess of five-tenths of one percent over the whole sample, these figures represent sixty percent lower and twenty-five percent higher rates of population growth due to one standard deviation higher level of aggregate poor aid, respectively.

[Table 5 about here.]

As an alternative remedy for the possibility that Poor Relief per Capita is endogenous we also ran 2-stage least square (2SLS) estimates. Accordingly, we used Black Death Impact and Usable Land as instruments for Poor Relief per Capita as well as the interaction of that variable with Year. Our working assumption here was that, consistent with the Malthusian mechanisms, these instruments came to bear on the levels - but not the growth rates - of county populations. In the second stage, we then used the predicted amounts of poor aid as the main explanatory variable for differences in the growth rates of county populations.

Our results are summarized in Table 6. First, as shown in the estimates in columns (1), (2), (4) and (5), our instruments do have explanatory power. But they are not particularly strong instruments as indicated by the Kleibergen-Paap, Wald and Hansen J statistics listed at the bottom of columns (3) and (6). The Anderson-Rubin and StockWright test statistics reported immediately below in those columns, however, indicate that our two endogenous regressors, Poor Relief per Capita and Year * Poor Relief per Capita, are jointly significant in the main estimation equation.

The key point here is that we see that aid to the poor has effects on population growth that are similar to those we produced earlier. Both of our IV specifications suggest that Poor Relief per Capita directly and statistically significantly reduced population growth but that, as time progressed, this effect was dissipating and turning positive. The coefficients on Poor Relief per Capita and Year * Poor Relief per Capita in columns (3) and (6) jointly suggest that the net effect of poor relief on population growth turned positive starting in 1786 and 1748, respectively.

[Table 6 about here.]

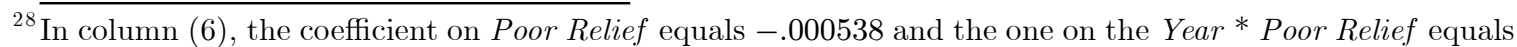
$.301 e^{-7}$. The standard deviation of Poor Relief equals 123.6, as shown in Table 1.A. Hence, in the year 1700 , the net effect comes out to $.123 .6 *\left(.301 e^{-7 *} 1700-123.6\right)=-.0033$. And, in 1815 , it nets out to $.123 .6 *\left(.301 e^{-7 * 1815-123.6)=.001 .}\right.$
} 
We also explored the extent to which these findings are driven by outliers. To that end, we ran robust regressions that omit extreme observations. ${ }^{29}$ Alternatively, we also ran regressions identical to those shown in Tables 3 through 6 but omitting Middlesex county which includes London. Our qualitative results were in line with those reported above, which is why we have chosen not to report them here (although they are available upon request).

In effect, these results validate Boyer's findings that aid to the poor generated faster rates of population growth - but only in the 19th century. Due to data available to us now starting in the mid-17th century and stretching through the early-19th century, we in fact identify that, for nearly a century and a half, aid to the poor was negatively associated with population growth. The only period for which we do not have data covers the five decades stretching from the adoption of the Old Poor Law in 1601 to 1650 . We cannot rule out that poor relief exerted a net positive impact on population growth in this early era too. Nevertheless, given that amounts of aid to the poor ramped up significantly over time and the Malthusian income effects inherently kick in with some lags, the likelihood that poor relief exerted positive and statistically significant net effects on population growth over the period between 1601 and 1650 is likely to be small.

\section{$5 \quad$ Aid to the Poor \& Social Unrest}

\subsection{Baseline Estimates}

We now turn to the relationship between poor relief and social stability.

In Table 7, we present our baseline results with Poor Relief per Capita observed at six points in 1685, 1750, 1776, 1784, 1803 and 1815 followed by Riots per Year accumulated and annualized over five corresponding intervals of time: 1686 to 1749, 1751 to 1775, 1777 to 1783,1785 to 1802,1804 to 1814 and 1816 to 1830 . All of these baseline regressions include region fixed effects, but to start things off we withhold county and year fixed effects until the regression in our next table. The estimates in the first three columns are based on Ordinary Least Square regressions, those in the final three columns rely on Poisson regressions, and all errors reported are clustered by region (i.e., north, middle, south). In columns (1) and (4), we have our most parsimonious specification that only controls for the amount of poor relief per capita in the preceding period, followed by those estimates in columns (2) and (5) that add county population levels and the number of lagged riots per year. In columns (3) and (6), we also include controls for county wealth and market dependency.

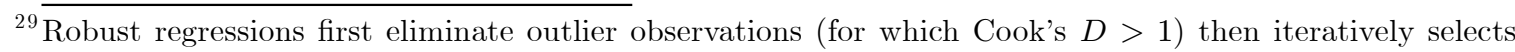
weights for the remaining observations to reduce the absolute value of the residuals.
} 
As shown, per-capita amount of poor relief in the preceding period is a consistently significant and negative predictor of yearly average riots in the subsequent period. In our OLS estimates, Poor Relief per Capita comes in statistically significant at the 95percent confidence level in two regressions and with a 90-percent significance in our most parsimonious regression shown in column (1). When we use Poisson regression instead, all four regressions yield negative and economically meaningful coefficients on Poor Relief per Capita, three of which being statistically significant at the 99-percent confidence level. Taking the column (3) estimates into account, we see that a one standard deviation increase in the county level aid that could be supplied to the poor (that is, an increase in Poor Relief per Capita equal to .293) would have reduced food riots within a county by .405, implying a reduction in food riots by about 50 percent.

As far as the control variables are concerned, including lagged values of the dependent variable improves regression fits as lagged food riots indicate generally significant mean reversions. We have no indication that wealthier counties saw systematically higher levels of food rioting, although there is clear evidence here that more populous counties experienced more food riots, on average. Law Enforcement comes in with its predicted negative sign in the two regressions this variable is included, although it does not produce statistical significance in either estimate. ${ }^{30}$ Finally, although not shown, our regional dummies generate a very strong geographic pattern according to which, ceteris paribus, counties in mid-England experienced more food riots than northern counties, and those in the south experienced even more than those counties in the middle.

\section{[Table 7 about here.]}

Our descriptive statistics show strong time trends in both aid to the poor and riots per annum. On this basis, the regression in the first column of Table 8 replicates the regression in the final column of the preceding table, this time also including year fixed effects. As shown, the inclusion of time fixed effects renders the negative impact of aid to the poor on food riots statistically insignificant.

This observation is reassuring given the history and importance of the Poor Law. As most other institutions, it had multiple implications, some of which evolved over time. Particularly important to our analysis is that, in the early nineteenth century, the authorities turned away from using poor relief to sustain social order. While in the sixteenth century, civic humanism and political centralism were important interests shaping policy toward the poor, by the mid seventeenth century, these "absolutist" initiatives appeared

\footnotetext{
${ }^{30}$ Law enforcement data were missing for a large number of counties. In these regressions, we assumed zero law enforcement expenditures for the missing observations, although regressions in which we used only the available data produced similar findings.
} 
"bankrupt intellectually because they were bankrupt financially" (Slack, 1999, p. 74). A mixed economy of welfare in which economic considerations played a larger role followed. By the late eighteenth century, the dominant economic consideration became the one we associate with the Malthusian check. Poor relief perpetuated the growth of the 'unproductive' poor and this process was deemed to be unsustainable (Slack 1999).

By the early nineteenth century, policy was progressively based on the view expressed, for example, in the Report on the Poor Law of 1817. The "compulsory contribution... from the funds originally accumulated from the work of others, could not fail in the process of time... to produce the unfortunate effect of abating those exertions on the part of the labouring classes... that this system: is perpetually encouraging and increasing the amount of misery it was designed to alleviate, creating at the same time an unlimited demand of funds" (p. 4). This concern with a Malthusian income effect dominated policy at the time. And as we illustrated in the section above, aid to the poor after the turn of the 19th century did, in fact, come to bear on population growth.

Given these considerations, we wanted to empirically investigate the extent to which the impact of poor relief on social stability started to dissipate after the 1810s. To that end, we separated the 1815 poor relief data and the subsequent food riots data covering the period between 1816 and 1830 from the rest of the sample and reran our OLS specification using these two subsamples. Results using the 1815 poor relief data are shown in column (2) of Table 8 and results based on the remaining time periods are shown in the following column. ${ }^{31}$ In both specifications, we still have regional fixed effects and in column (3) we include year fixed effects as well. ${ }^{32}$

The results in column (2) provide additional evidence of Malthusian income effects (e.g., Boyer 1989), according to which higher amounts of poor relief per capita are associated positively and significantly with more riots. But focusing on the period between 1685 and 1814, as we do in column (3), we see that the social stability inducing effects of aid to the poor are restored. Here we see that more populous counties experienced more rioting and the point estimate of the negative coefficient on Poor Relief per Capita is significant at the 90-percent confidence level. Once we exclude the 1815 data from our sample, the quantitative impact of aid to the poor rises a bit more, with a one standard deviation increase in poor aid generating nearly a 60 percent reduction in food riots.

In the final three columns of Table 8, we rerun the regression in column (3) this time replacing the region fixed effects with county fixed effects and clustering the error terms

\footnotetext{
${ }^{31}$ The time periods cover the five points in time when Poor Relief per Capita is observed in 1685, 1750, 1776, 1784 and 1803 followed respectively by Riots per Year covering the windows of 1686 to 1749,1751 to 1775 , 1776 to 1783,1785 to 1802 and 1804 to 1814 .

${ }^{32}$ Since column (2) estimates rely on only one time period, year fixed effects cannot be included in that specification.
} 
by county. In these regressions, Poor Relief per Capita continues to enter the regressions negatively and, in two of the three regressions where we estimate using a generalized linear model (within the negative binomial family) and a Poisson specification, it comes in with a 99 -percent statistical significance. ${ }^{33}$

[Table 8 about here.]

In our final set of baseline estimates, we explore whether aid to the poor primarily affected the incidence of food riots or it came to bear on the frequency of those kinds of riots as well. To that end, we created an incidence indicator, I(Riots per Year), which took the value of one if there were any riots in the county within the specified period of time and zero otherwise. In Table 9, we report the results of three linear probability models in which this incidence variable is regressed on Poor Relief per Capita and other control variables. Then, we estimate three OLS regressions that explore if the frequency of food riots depended on aid to the poor conditional on the predicted food riot incidence derived from the corresponding first-stage indicator being positive. Here we have some consistent support that Poor Relief per Capita primarily came to bear on whether or not food riots occurred at all. In all of our first three regressions, aid to the poor comes in negatively and statistically significant at the 99-percent confidence levels. However, when we explore the role of poor relief on the frequency of food riots in counties and during times when at least one food riot occurred, as we do in columns (4) through (6), Poor Relief per Capita has no meaningful impact.

[Table 9 about here.]

\subsection{Alternative Specifications \& Robustness}

We experimented with various alternative specifications and controls in order to establish the robustness of the role of aid to the poor in social unrest in England between the late-17th and early-19th centuries.

First, we ran a set of regressions without county and year fixed effects to see the extent to which controlling for such invariant determinants of social unrest influences the role of aid to the poor on rioting. Second, we turned to an alternative data source in Charlesworth (1983) for social protests in England to see if our key results would remain intact using alternate data sources and coverages of time periods. Using Charlesworth we were also able to investigate if other kinds of riots that should hypothetically not be as responsive

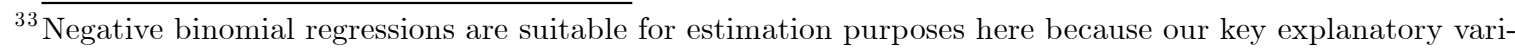
able, Poor Relief per Capita, as well as some of our other control variables are clustered around realtively small values.
} 
to aid to the poor, such as land and enclosure protests as well as militia uprisings, were affected by aid to the poor. Third, we explored alternative measures of aid to the poor as the main explanatory variable in variations in food riots. In what follows, we discuss some of these empirical estimates in turn.

In Table 10, for example, we report three OLS regressions where the incidence of riots is the dependent variable, starting with an estimate that has neither time nor county fixed effects. In all three regressions, we include the same set of controls: the lagged dependent variable, county population levels and our two proxies for wealth and market dependency. In one of the regressions in this table, we find evidence of mean reversion in food rioting, with Riots per Year $_{t-1}$ entering the regression with a highly significant and negative coefficient. Likewise, we also confirm in three of the seven estimates shown here that more populous counties experienced more rioting, ceteris paribus. Most importantly, however, we find that county and year fixed effects are both important in our estimates although neither county nor time fixed effects impact the statistical significance of Poor Relief per Capita. The inclusion of county fixed effects do reduce the quantitative impact of aid to the poor on food rioting thus suggesting that some unobservable and time-invariant county characteristics influenced food riots as well.

Year fixed effects are important too and, in an attempt to better identify time trends, we ran two regressions shown in columns (4) and (5) that include Year linearly and nonlinearly, respectively. While the effect of poor relief on food riots remains negative in both estimates and it is statistically significant in one of them, we see that there is a strong nonlinear time trend in the frequency of food riots. Taken together, the coefficient estimates for Year and $Y e a r^{2}$ imply that food riots were increasing at a decreasing rate for the whole time period over which we estimate our model (i.e., from 1685 to 1814).

In our final two regressions listed in Table 9, we experimented with two additional controls that were available to us. In column (6), we removed year fixed effects and the linear and non-linear year controls and ran a regression with wheat price data from Clark (2003). Doing so, we are able to verify that wheat price fluctuations did positively correlate with food riots, providing us further proof of the Malthusian income impact of food price variations. ${ }^{34}$ Nevertheless, the significant and quantitatively meaningful role of aid to the poor in dampening food riots remained intact. In the final column of the table, we entered an indicator of whether the county in question was in the north, the middle or the south (recall that our region code progressively increases, going from 1 for northern counties to 3 in southern counties). As shown, the relationship between Poor Relief per Capita and Riots per Year remains negative and statistically significant at the 99-percent confidence

\footnotetext{
${ }^{34}$ Recall from Section 4 that Wheat Price exhibited consistently strong Malthusian effects on population growth.
} 
interval. However, we do find that, ceteris paribus, southern counties were more prone to food riots, despite the fact that the raw correlation between Riots per Year and Region is negative (see Table 1.B).

[Table 10 about here.]

A potential source of bias and endogeneity in our main explanatory variable, Poor Relief per Capita, is that county population levels could be endogenous with respect to the amount of county resources that were available for aid to the poor. However, as we explained in Section 4 above, the total amount of public resources available for aid to the poor, Poor Relief, is more immune to this problem, because it represents the county level revenues collected net of collection costs.

In our next table, we reran our baseline regressions, this time using Poor Relief as our main explanatory variable. These estimates, which all include year and county fixed effects and cluster the error terms at the county level, produce statistically significant and negative effects of Poor Relief on I(Riots/Year) in all six regressions. Unlike the estimates involving Poor Relief per Capita, these estimates do not suggest that wealthier and more populous counties experienced more riots, which in all likelihood, was manifested in such counties having more total resources available for aid to the poor. In any case, the effect of poor relief on food riots is quantitatively large and in line with our earlier estimates using Poor Relief per Capita: for example, taking the estimate in column (3), we find that a one standard deviation higher amount of resources allocated to Poor Relief, which as shown in the top panel of Table 1, comes out to 123.6 (in thousands of British pounds), generates a .394 reduction in the number of Riots per Year. Given that the average of food riots in our sample is .779, this corresponds to a 51-percent dampening impact which is remarkably close to the 53 percent we derived using our baseline regressions with Poor Relief per Capita.

[Table 11 about here.]

Our main data source for social unrest and disorder data is Bohstedt (2010). Nevertheless, we have an alternative resource in Charlesworth (1983) which provides periodic maps of social protests in England between the years of 1548 and 1900. We coded the numbers of food riots and protests involving land and enclosure disputes in Charlesworth to have at our disposal two additional dependent variables. First, we produced an alternative series of food riots based solely on the data in Charlesworth which we labeled as Charlesworth Riots. The data we use in our baseline regressions include those in Charlesworth but are also based on additional sources, thereby making our baseline food riots data more comprehensive than those in Charlesworth. In addition, the years of coverage differ between 
the two datasets, providing us an opportunity to test the empirical ties between aid to the poor and social disruptions over slightly different time horizons. ${ }^{35}$

In Table 12, we reproduce our baseline regressions with year and county fixed effects, this time using Charlesworth Riots as our dependent variable. As shown, all of our six estimates produce highly significant and negative coefficients on poor relief with five of the six estimates generating statistical significance at the 99-percent confidence level and one yielding a negative coefficient that is within the 95-percent confidence band. As we already pointed out, the Charlesworth data enable us to explore the role of poor aid on food riots using a different source and somewhat different time intervals although, on the downside, we have significantly fewer observations once we also control for lagged food riots across the counties. Despite fewer observations and a different data source, all the results shown in Table 12 replicate and confirm our earlier findings: there is systematic mean reversion in food riots within counties and higher levels of county population tend to generate more rioting. However, the availability of more public resources that could be devoted to poor relief per capita helps to statistically significantly depress riots in all of our six empirical specifications.

[Table 12 about here.]

To the extent that riots and social upheavals were politically driven or they were less economically motivated, they should not have been contained via the amount of countylevel variations in resources available for aid to the poor. An important benefit of using the data supplied by Charlesworth (1983) is that rural protests in England are broken down by their type and motive. Thus, we were able to compile Charlesworth's data on land and enclosure protests over the time periods for which we have commensurate poor relief and control data. Using the same source, we were also able to construct an alternative series on clubmen and militia protests in England for the period between 1650 and $1798 .{ }^{36}$

Table 13 presents the regressions in which English land and enclosure protests were regressed on Poor Relief per Capita as well as the set of our key control variables, including

\footnotetext{
${ }^{35}$ Recall that we have poor relief data across the 39 English counties at six points in time: the first observations are for 1685, and the rest are for 1750, 1776, 1784, 1803 and 1815. Our baseline primary social disorder data are then observed in six subsequent corresponding windows of time. Consequently, we can work with a panel of six time periods when we use our baseline data.

By contrast, the Charlesworth dataset enables us to observe social disruptions through 1818, although it does not provide a breakdown of the data on social unrest for the interval between 1776 and the 1790s. Hence, with the Charlesworth data, we are able to explore the link between poor aid and social unrest in the following way: aid to the poor observed in 1685, 1776 and 1803; food riots observed between 1686 and 1749, from 1777 to 1783 , and between 1804 and 1814. Thus, this dataset allows us to utilize a panel covering 3 time periods.

${ }^{36}$ Results using the clubmen and militia protests were similar to the ones we produced using land and enclosure riots. Thus, we have chosen not to report them here, although they are available upon request.
} 
the lagged dependent variable, Population, Wealth and Market Dependency. As shown, wealthier, more populous and market dependent counties observed more land and enclosure protests. Most importantly, however, we see that poor relief exerted positive and statistically significant effects on land and enclosure related social disruptions, in stark contrast to its negative impact on food riots.

[Table 13 about here.]

In order to gain further insight on the relationship between aid to the poor and food riots, we next investigate the role of various county-level variables that cannot be included when county fixed effects are controlled for. In all six regressions listed in Table 14, we control for year and region fixed effects. In all columns, we include Black Death Impact Black Death Impact, measuring the difference in the county population estimates between 1290 and 1379, thereby proxying for the impact of the Black Death plague on the counties. In a Malthusian regime and provided that the impact of the Black death persisted for long periods of time as some historians suggested, one would expect those counties that suffered higher losses during the plague to have experienced positive income shocks in the subsequent periods and, thus, fewer food riots. In fact, as with our population estimates using regional fixed effects, Black Death Impact enters with the opposite (positive) sign although it comes in statistically significant in all six regressions shown in Table 14. In the subsequent regressions, we include our two other time invariant, county-level variables, Usable Land and London Distance. Both of these variables exhibit predictive power in all four regressions in which they are included with Usable Land generating positive and significant coefficients and distance to London showing statistically significant negative effects throughout. Most importantly, however, we see that the negative relationship between poor relief and riots remains highly intact, with the coefficient on Poor Relief Per Capita being negative and significant in all six specifications.

[Table 14 about here.]

Recall that the impact of poor relief on food riots had dissipated after the turn of the 19th century, the institutional and historiographic underpinnings of which we already discussed. This, in essence, is why we truncated our sample period to exclude observations from 1815 and thereafter. Nevertheless, it would be illuminating to consider the whole sample and estimate the role of poor relief on food riots in specifications where the impact of Poor Relief per Capita is conditional on time. The results of this exercise are reported in Table 15. The first three columns present estimates that include county fixed effects. The last three columns report results using region fixed effects and including instead the time invariant, county-level variables we utilized in our previous table. 
As shown, these results are very much in line with the time-conditional role of aid to the poor on population growth we detected earlier. In all specifications, Poor Relief per Capita enters negatively whereas, in five of those, it also enters statistically significantly. And the Year ${ }^{*}$ Poor Relief per Capita interaction enters positively in all six regressions, with four regressions generating statistically significant positive coefficients. Taking in turn the four regressions in which both of these key explanatory variables are statistically significant, we see that the net effect of aid to the poor on riots turns positive in the years of 1863, 1843, 1852, and 1865, respectively. Since the Old Poor Law was terminated in 1834 , this once again validates the fact that poor relief had quantitatively minimal to no role in social stability after the turn of the 19th century.

[Table 15 about here.]

What about reverse causality and the endogeneity of or main explanatory variable, Poor Relief per Capita? As Rushton (1989, p. 137) documents, the historiography of the Old Poor Law suggests that poor relief expenditures varied positively with harvest failures and the propensity of food riots. Hence, if anything, the reduced-form results above could be reflecting some attenuation bias.

Nevertheless, in order to empirically deal with endogeneity, we also ran 2-stage least square (2SLS) estimates that are analogous to those shown in Table 6. That is, we used Black Death Impact and Usable Land as instruments for Poor Relief per Capita as well as the interaction of that variable with Year. In the second stage, we then used the predicted amounts of poor aid as the main explanatory variable for differences in the frequency of food riots across the English counties. Our results are summarized in Table 16. Once again, our instruments have explanatory power, although they are not particularly strong instruments as indicated by the Kleibergen-Paap, Wald and Hansen J statistics. Nevertheless, the Anderson-Rubin and Stock-Wright test statistics indicate that our two endogenous regressors, Poor Relief per Capita and Year * Poor Relief per Capita, are jointly significant in the main estimation equation. The results here are consistent with those listed in our previous table. Both of our IV specifications suggest that Poor Relief per Capita directly and statistically significantly reduced rioting but that, as time progressed, this effect was diminishing. The coefficients on Poor Relief per Capita and Year * Poor Relief per Capita in columns (3) and (6) jointly suggest that the net effect of poor relief on population growth turned positive starting in 1852 and 1848, respectively. And, once again, both of those dates follow the termination of the Old Poor Law, suggesting that the net impact of poor relief on rioting did not turn positive when the Old Poor Law was in effect although it became fairly small after the 18th century.

[Table 16 about here.] 


\section{Conclusion}

The Old Poor Law was enacted in 1601, at least in part, to maintain social order. It formalized a system of a social safety-net that lasted, with some modifications, until 1834 .

Contemporary proponents of the Old Poor Law recognized the destabilizing impact of the transition to a modern economy. They argued that rapid technological and organizational changes could have negative pecuniary externalities, displacing labor or influencing wages, thereby sowing the seeds of social discontent and instability. Extending poor relief through some income redistribution could have fostered social peace and stability, thereby smoothing the social repercussions of the creative destruction inherent in the developmental process leading to and encompassing the Industrial Revolution.

By contrast, the critics of the Old Poor Law, led most prominently by Thomas Malthus, were skeptical that aid to the poor would buy social stability. Instead, they believed that higher incomes among the poor would translate into faster population growth, depressing wage incomes and having, in the long-run, no positive effect on the propensity of social upheavals.

Previous studies have, indeed, documented the extent of social disorder associated with the transition to the modern economy in England in the run-up to the Industrial Revolution. They have also supplied convincing empirical support for the Malthusian argument that aid to the poor fostered population growth. A serious shortcoming of these illuminating lines of research stemmed from the fact that they focused on very short periods of time around the 1820s, more than two centuries after the Poor Law was enacted. Furthermore, due to lack of relevant data, none of these studies were able to assess if poor relief came to bear on social disturbances at all.

To carry out a comprehensive and dynamic assessment of the impact of the Old Poor Law both on population growth and social stability, we assembled an extensive panel data covering 39 English counties over the period from 1650 to 1815. The analysis reveals a more complex reality which neither arguments fully captures.

The impact of the Old Poor Law evolved over time. Specifically, depending on the exact empirical specification and controls, aid to the poor reduced population growth through the 1780 s or 1820 s when it began to exert significantly positive effects. Moreover, the Old Poor Law contributed to social order prior to the late-18th or early-19th centuries. In contrast, after the first decade of the 19th century, poor relief began to generate population growth and had no effect on social order.

The causal mechanisms behind these empirical findings and their inter-relations with the growth process are yet to be examined. It may well be, however, that the Old Poor Law was crucial to England's transition to a modern economy. In the transition's early stages, 
the labor market was unable to relocate labor sufficiently fast to prevent destitution, violent responses, and social disorder. Poor relief fostered stability and prevented disorder that may have otherwise undermined growth. In the later stages of the transition, the demand for labor and particularly child labor increased. The Poor Law thus fostered population growth; children were subsidized while parents benefitted from their labor. A larger working population and lower wages, however, contributed to destitution and social disorder. 


\section{Bibliography}

Abstract of the Answers and Returns Made Pursuant to an Act, Passed in the 43d Year of His Majesty King George III. 1803-04 Entitled, "An Act for Procuring Returns Relative to the Expense and Maintenance of the Poor in England.," Ordered by the House of Commons, July 10, 1804.

Archer, John E. 2000. Social Unrest and Popular Protest in England, 1780-1840. Cambridge: Cambridge University Press.

Buckatzsch, E.J. 1950. "The Geographical Distribution of Wealth in England, 10861843: An Experimental Study of Certain Tax Assessments," The Economic History Review, New Series, Vol. 3, No. 2, pp. 180-202.

Beier, A.L., 1985. Masterless Men: The Vagrancy Problem in England, 1560-1640.

Ben-Amos (Krausman), Ilana. 2008.The Culture of Giving: Informal Support and Gift-Exchange in Early Modern England. Cambridge: Cambridge University Press.

Blaug, M. 1963. "The Myth of the Old Poor Law and the Making of the New," Journal of Economic History, 23, 151-84.

Blaug, M. 1964. "The Poor Law Report Re-examined," Journal of Economic History, $24,229-45$.

Bohstedt, J. 2010. The politics of provisions: food riots, moral economy, and market transition in England, 1550-1850. Ashgate: Farnham (UK) and see data in: Bohstedt, John, 'Censuses of Food Riots 1527-1867', posted at http://web.utk.edu/ bohstedt/

Boyer, G. R. 1989. "Malthus Was Right after All: Poor Relief and Birth Rates in Southeastern England," Journal of Political Economy, 97:1, February, 93-114.

Boyer, George R. 1990. An Economic History of the English Poor Law, 1750-1850. Cambridge: Cambridge University Press, 1990.

Broadberry, Stephen, Bruce Campbell, Alexander Klein, Mark Overton and Bas van Leeuwen. 2011. British Economic Growth, 1270-1870: An Output -based Approach". LSE. Link to database at: http://www2.lse.ac.uk/economicHistory/whosWho /profiles/sbroadberry.aspx.

Brenner, Robert. 1987. Agrarian Class Structure and Economic Development in PreIndustrial Europe. In T.H. Aston and C.H.E. Philpin (eds), The Brenner Debate. Agrarian Class Structure and Economic Development in Pre-Industrial Europe. Cambridge: Cambridge University Press. Pp. 10-63.

Charlesworth, A. 1983. An Atlas of Rural Protest in Britain, 1548-1900, (ed.), (Philadelphia, PA: University of Pennsylvania Press). 
Clark, G. 2003. "The Price History of English Agriculture, 1209-1914," University of California, Davis

Colquhoun, P. 1806. Treatise on Indigence Exhibiting: A General View Of The National Resources For Productive Labor, London.

Committee on the Poor Laws. 1817. Great Britain, Parliament. House of Commons. Select Committee on the Poor Laws. Report from the Select Committee on the Poor Laws: with the minutes of evidence taken before the committee : and an appendix. [London?: s.n]

Committee on Poor Rate Returns. 1821-26. Great Britain. Report from the Select Committee on Poor Rate Returns. [London?: s.n]

de Vries, Jan and Ad van der Woude. 1997. The First Modern Economy: Success, Failure, and Perseverance of the Dutch Economy, 1500-1815. Cambridge: Cambridge University Press

Dyson, Richard. 2009. Welfare Provision in Oxford During the Latter Stages of the Old Poor Law, 1800-1834. The Historical Journal, 52, 4, pp. 943-962

Eden, F. M. 1797. The State Of The Poor; Or, An History Of The Labouring Classes In England, From The Conquest To The Present Period. Vols. I-III. London: J. Davis.

Eden, F. M. 1800. Estimates of the Number of Inhabitants in Great Britain and Ireland. London: J. Wright.

Greif, A. 2006. Institutions and the Path to the Modern Economy. Cambridge, UK: Cambridge University Press.

Greif, A. M. Iyigun and D. Sasson.2011. "Risk, Institutions and Growth: Why England and not China?,"IZA Working Paper Series, No: 5598, March.

Greif, A. M. Iyigun and D. Sasson. 2012. "Risk-Sharing Institutions, Social Norms and Economic Development," International Economic Association Conference Volume, May.

Greif, A. and M. Iyigun. 2013. "Social Organizations, Risk-Sharing Institutions and Industrialization," American Economic Review (P \& P), May.

Hale, Matthew, Sir, 1683. A Discourse Touching Provision for the Poor.

Hartwell, Ronald Max. 1981. Taxation in England During the Industrial Revolution. Cato Journal, Vol. 1, No. 1 (Spring), 129-153

Lowndes, W and J. Debrett. 1789. Introduction to the Statistical Tables of the Principal Empires, Kingdoms and States in Europe, London: Stationers Hall/

Harris, Bernard. 2004. Public Health, Nutrition, and the Decline in Mortality: The McKeown Thesis Revisited. Social History of Medicine 17(3): 379-407. 
Huzel, J. P. (1969). "Malthus, the Poor Law, and Population in Early NineteenthCentury England," Economic History Review, 2d ser., 22. December: 430-52.

Huzel, J. P (1980). "The Demographic Impact of the Old Poor Law: More ReHexions on Malthus," Economic History Review, 2d ser., 33. August: 367-81.

Kelly, M. and C. Ógrada. 2008. The Poor Law versus Positive Check: Living standards and Mortality in England since the Middle Ages. UC Dublin working paper.

King, S. 2000. Proverty and Welfare in England, 1700-1850. (Manchester, UK: Manchester University Press).

Kussmaul, A. 1989. A General View of the Rural Economy of England, 1538-1840. (Cambridge, UK: Cambridge University Press).

Lindert, P. H. 2004. Growing Public. Cambridge, UK: Cambridge University Press.rtwell, Ronald Max. 1981. Taxation in England During the Industrial Revolution. Cato Journal, Vol. 1, No. 1 (Spring), 129-153

Lowndes, W and J. Debrett, 1789. Introduction to the Statistical Tables of the Principal Empires, Kingdoms and States in Europe, London: Stationers Hall/

Milanovic, Branko, Peter Lindert and Jeff Williamson. 2007. Measuring Ancient Inequality. NBER working paper.

Malthus, T. R. 1872. An Essay on the Principle of Population. 7th ed. London: Reeves and Turner. Reprint. 2 vols. London: Dent, 1914.

Mokyr, J. 2002. "Why was the Industrial Revolution a European Phenomenon?" Supreme Court Economic Review, 9.

Mokyr, J. 2010. The Enlightened Economy: An Economic History of Britain 1700-1850. New Haven, CT: Yale University Press.

Nicolini, E. A. 2007. "Was Malthus Right? A VAR Analysis of Economic and Demographic Interactions in Pre-industrial England." European Review of Economic History, 11: $99-121$.

Outhwaite, R. B. 1991. Dearth, Public Policy and Social Disturbance in England 15501800 (New Studies in Economic and Social History). Cambridge University Press.

Poor Law Board. 1854. Parliament. House of Commons. Sixth Annual Report of the Poor Law Board. 1853. London: Her Majesty's Stationery Office.

Pratt, John Tidd, 1834. The Act for the Amendment and Better Administration of the Laws Relating to thhe Poor in England and Wales. Second ed. London: B. Fellowes.

Reynolds, S. 1984. Kingdoms and Communities in Western Europe, 900-1300. Oxford:Clarendon Press. 
Richardson, G. 2005. "The Prudent Village: Risk Pooling Institutions in Medieval English Agriculture." Journal of Economic History, 65(2): 386-413.

Rushton, P. (1989). "The Poor Law, the Parish and the Community in Northeast England, 1600 - 1800" Northern History, 25: 135 - 52.

Slack, P. 1990. The English Poor Law, 1531-1782. London, UK: Macmillan.

Slack, P. 1999. From Reformation to Improvement: Public Welfare in Early Modern England. (Oxford, UK: Oxford University Press).

Smith, R. 2008. "Social Security as a Developmental Institution? Extending the Solar Case for the Relative Efficacy of Poor Relief Provisions under the English Old Poor Law." Brooks World Poverty Institute Working Paper No. 56

Solar, P. M. 1995. "Poor Relief and English Economic Development before the Industrial Revolution." The Economic History Review, New Series, 48 (1): 1-22.

Tabellini, G. 2005. "Culture and Institutions: Economic Development in the Regions of Europe," IGIER discussion paper.

Woodcroft, Bennet. 1863. Brief Biographies of Inventors of Machines for the Manufacture of Textile Fabrics. London: Longman. 
Table 1.A.: Descriptive \& Summary Statistics

\begin{tabular}{|l|c|c|c|c|c|}
\hline & \multicolumn{5}{|c|}{ Summary Statistics } \\
\hline VARIABLE & Obs. & Mean & Std. Dev. & Min & Max \\
\hline Poor Relief & 233 & 79.0 & 123.6 & .86 & 1098 \\
\hline Poor Relief per Capita & 233 & .374 & .293 & .027 & 1.33 \\
\hline Riots & 273 & 4.31 & 8.56 & 0 & 76 \\
\hline Riots per Year & 273 & .779 & 1.72 & 0 & 10.9 \\
\hline Population & 273 & 177.5 & 162.0 & 13.8 & 1006 \\
\hline Population Growth & 234 & .0054 & .0038 & -.005 & .017 \\
\hline Wealth & 271 & 19.6 & 10.84 & 1 & 39 \\
\hline Market Dependency & 270 & .601 & .310 & 0 & 1 \\
\hline Wheat Price & 273 & 6.41 & 2.16 & 4.01 & 10.5 \\
\hline London Distance & 273 & 127.8 & 110 & 0 & 610 \\
\hline Usable Land & 273 & 755.3 & 530.5 & 90 & 3100 \\
\hline Law Enforcement & 273 & 2.15 & 3.70 & 0 & 28.8 \\
\hline Black Death Impact & 273 & -42.77 & 24.19 & -79 & 77 \\
\hline Region & 273 & 2.38 & .739 & 1 & 3 \\
\hline Charlesworth Food Riots & 156 & 8 & 12.5 & 0 & 76 \\
\hline Charlesworth Food Riots/Yr. & 156 & .258 & .464 & 0 & 3.04 \\
\hline Charlesworth Land Protests & 156 & .711 & 1.43 & 0 & 7 \\
\hline Charlesworth Land Prts./Yr. & 156 & .014 & .028 & 0 & .143 \\
\hline Year & 273 & 1752 & 57.5 & 1650 & 1815 \\
\hline
\end{tabular}


Table 1.B.: The Correlation Matrix

\begin{tabular}{|l|c|c|c|c|c|c|c|c|c|c|}
\hline Obs. & \multicolumn{9}{|c|}{ The Correlation Matrix } \\
\hline & PR & PRPC & Riots & Riots $/$ Yr & Popn & Pop. Gr. & Wealth & Mrkt. Dp. & Region & London D. \\
\hline Poor Relief & 1 & & & & & & & & & \\
\hline Poor Relief per Capita & .594 & 1 & & & & & & & & \\
\hline Riots & -.053 & -.171 & 1 & & & & & & & \\
\hline Riots per Year & -.077 & -.165 & .884 & 1 & & & & & & \\
\hline Population & .742 & .172 & .160 & .099 & 1 & & & & & \\
\hline Population Growth & -.050 & -.243 & -.065 & .039 & .114 & 1 & & & & \\
\hline Wealth & -.037 & -.096 & -.016 & -.023 & -.285 & -.020 & 1 & & & \\
\hline Market Dependency & .137 & -.134 & .174 & .116 & .324 & .208 & .147 & 1 & & \\
\hline Region & .110 & .265 & .005 & .036 & -.091 & -.278 & -.352 & -.275 & 1 & \\
\hline London Distance & -.023 & -.277 & .161 & .099 & .332 & .240 & .445 & .299 & -.727 & \\
\hline Year & .415 & .677 & .038 & .040 & .232 & -.123 & .016 & .024 & -.020 & \multicolumn{1}{|c|}{.014} \\
\hline
\end{tabular}

\begin{tabular}{|l|c|c|c|c|c|c|c|c|c|c|}
\hline Obs. 116 & \multicolumn{7}{|c|}{ The Correlation Matrix } & Law En. & Bl. Dth. \\
\hline & PR & PRPC & Riots & Riots/Yr & Popn & Pop. Gr. & Cost L. & Wheat Pr. & Law \\
\hline Poor Relief & 1 & & & & & & & & & \\
\hline Poor Relief per Capita & .594 & 1 & & & & & & & & \\
\hline Riots & -.053 & -.171 & 1 & & & & & & & \\
\hline Riots per Year & -.077 & -.165 & .884 & 1 & & & & & & \\
\hline Population & .742 & .172 & .160 & .099 & 1 & & & & & \\
\hline Population Growth & -.050 & -.243 & -.065 & .039 & .114 & 1 & & & & \\
\hline Cost of Living & .494 & .800 & -.066 & -.088 & .229 & -.217 & 1 & & & \\
\hline Wheat Price & .432 & .743 & .020 & -.054 & .200 & -.262 & .706 & 1 & & \\
\hline Law Enforcement & .849 & .635 & -.051 & -.088 & .636 & -.045 & .677 & .526 & 1 & \\
\hline Black Death Impact & .117 & -.022 & .155 & .121 & .179 & .158 & -.007 & -.008 & .098 & 1 \\
\hline Year & .414 & .677 & .040 & .041 & .231 & -.125 & .809 & .809 & .538 & -.013 \\
\hline
\end{tabular}


Table 2: Poor Relief \& Population Growth-Baseline Regressions

\begin{tabular}{|c|c|c|c|c|c|c|}
\hline VARIABLES & $\begin{array}{c}\text { (1) } \\
\text { OLS } \\
\text { Pop. Growth } \\
\end{array}$ & $\begin{array}{c}\text { (2) } \\
\text { OLS } \\
\text { Pop. Growth } \\
\end{array}$ & $\begin{array}{c}\text { (3) } \\
\text { OLS } \\
\text { Pop. Growth } \\
\end{array}$ & $\begin{array}{c}(4) \\
\text { OLS } \\
\text { Pop. Growth } \\
\end{array}$ & $\begin{array}{c}\text { (5) } \\
\text { OLS } \\
\text { Pop. Growth } \\
\end{array}$ & $\begin{array}{c}\text { (6) } \\
\text { OLS } \\
\text { Pop. Growth } \\
\end{array}$ \\
\hline Poor Relief per Capita & $\begin{array}{c}0.00129 \\
(0.00117)\end{array}$ & $\begin{array}{c}0.00245^{* *} \\
(0.00109)\end{array}$ & $\begin{array}{c}0.00393^{* * *} \\
(0.000757)\end{array}$ & $\begin{array}{c}0.00539^{* * *} \\
(0.00156)\end{array}$ & $\begin{array}{c}0.00563^{* * *} \\
(0.00148)\end{array}$ & $\begin{array}{c}0.00750^{* * * *} \\
(0.00139)\end{array}$ \\
\hline Year & $\begin{array}{c}3.64 \mathrm{e}-05^{* * *} \\
(6.86 \mathrm{e}-06)\end{array}$ & $\begin{array}{c}3.09 \mathrm{e}-05^{* * *} \\
(6.64 \mathrm{e}-06)\end{array}$ & $\begin{array}{c}1.83 \mathrm{e}-05^{* * *} \\
(5.54 \mathrm{e}-06)\end{array}$ & $\begin{array}{c}4.83 \mathrm{e}-05^{* * *} \\
(4.88 \mathrm{e}-06)\end{array}$ & $\begin{array}{c}4.80 \mathrm{e}-05^{* * *} \\
(4.95 \mathrm{e}-06)\end{array}$ & $\begin{array}{c}3.67 \mathrm{e}-05^{* * *} \\
(3.82 \mathrm{e}-06)\end{array}$ \\
\hline Population & $\begin{array}{l}6.18 \mathrm{e}-06^{*} \\
(3.06 \mathrm{e}-06)\end{array}$ & $\begin{array}{c}6.02 \mathrm{e}-06^{* *} \\
(2.86 \mathrm{e}-06)\end{array}$ & $\begin{array}{l}1.26 \mathrm{e}-05^{* *} \\
(4.69 \mathrm{e}-06)\end{array}$ & $\begin{array}{c}9.86 \mathrm{e}-07 \\
(4.44 \mathrm{e}-06)\end{array}$ & $\begin{array}{c}4.53 \mathrm{e}-07 \\
(4.14 \mathrm{e}-06)\end{array}$ & $\begin{array}{c}1.15 \mathrm{e}-05^{* * *} \\
(4.22 \mathrm{e}-06)\end{array}$ \\
\hline Wheat Price & & & & $\begin{array}{c}-0.000647^{* * *} \\
(0.000147)\end{array}$ & $\begin{array}{c}-0.000658^{* * *} \\
(0.000140)\end{array}$ & $\begin{array}{c}-0.000828^{* * *} \\
(0.000133)\end{array}$ \\
\hline Wealth & & & & $\begin{array}{c}-5.97 \mathrm{e}-05^{*} \\
(3.25 \mathrm{e}-05)\end{array}$ & $\begin{array}{c}-6.11 \mathrm{e}-05^{*} \\
(3.05 \mathrm{e}-05)\end{array}$ & $\begin{array}{l}-3.65 \mathrm{e}-05 \\
(4.29 \mathrm{e}-05)\end{array}$ \\
\hline Market Dependency & & & & $\begin{array}{l}0.00270^{* * *} \\
(0.000714)\end{array}$ & $\begin{array}{l}0.00232^{* * *} \\
(0.000766)\end{array}$ & $\begin{array}{c}0.000524 \\
(0.000764)\end{array}$ \\
\hline Usable Land & & & & $\begin{array}{l}-2.04 \mathrm{e}-07 \\
(9.84 \mathrm{e}-07)\end{array}$ & $\begin{array}{c}1.03 \mathrm{e}-06 \\
(1.03 \mathrm{e}-06)\end{array}$ & \\
\hline London Distance & & & & $\begin{array}{l}9.69 \mathrm{e}-06^{* *} \\
(4.34 \mathrm{e}-06)\end{array}$ & $\begin{array}{l}-4.55 \mathrm{e}-06 \\
(7.24 \mathrm{e}-06)\end{array}$ & \\
\hline Black Death Impact & & & & $\begin{array}{l}2.13 \mathrm{e}-05^{* *} \\
(8.46 \mathrm{e}-06)\end{array}$ & $\begin{array}{c}4.01 \mathrm{e}-05^{* * *} \\
(1.01 \mathrm{e}-05)\end{array}$ & \\
\hline Observations & 233 & 233 & 233 & 230 & 230 & 230 \\
\hline R-squared & 0.368 & 0.397 & 0.691 & 0.478 & 0.517 & 0.750 \\
\hline
\end{tabular}

Region fixed effects included in columns (2) and (5). County fixed effects included in columns (3) and (6).

Standard errors clustered by county in parentheses.

*** $\mathrm{p}<0.01,{ }^{* *} \mathrm{p}<0.05,{ }^{*} \mathrm{p}<0.1$ 
Table 3: Poor Relief \& Population Growth-with Time and Poor Relief Interactions

\begin{tabular}{|c|c|c|c|c|c|c|}
\hline VARIABLES & $\begin{array}{c}\text { (1) } \\
\text { OLS } \\
\text { Pop. Growth } \\
\end{array}$ & $\begin{array}{c}\text { (2) } \\
\text { OLS } \\
\text { Pop. Growth } \\
\end{array}$ & $\begin{array}{c}\text { (3) } \\
\text { OLS } \\
\text { Pop. Growth } \\
\end{array}$ & $\begin{array}{c}\text { (4) } \\
\text { OLS } \\
\text { Pop. Growth } \\
\end{array}$ & $\begin{array}{c}\text { OLS } \\
\text { OLs. Growth } \\
\text { Pop. }\end{array}$ & $\begin{array}{c}\text { (6) } \\
\text { OLS } \\
\text { Pop. Growth }\end{array}$ \\
\hline Poor Relief per Capita & $\begin{array}{c}-0.352^{* * *} \\
(0.0705)\end{array}$ & $\begin{array}{c}-0.299^{* * *} \\
(0.0652)\end{array}$ & $\begin{array}{c}-0.248^{* * *} \\
(0.0626)\end{array}$ & $\begin{array}{c}-0.269 * * * \\
(0.0853)\end{array}$ & $\begin{array}{c}-0.236^{* * *} \\
(0.0704)\end{array}$ & $\begin{array}{l}-0.0819 \\
(0.0669)\end{array}$ \\
\hline Year & $\begin{array}{c}1.01 \mathrm{e}-05 \\
(7.45 \mathrm{e}-06)\end{array}$ & $\begin{array}{c}1.11 \mathrm{e}-05 \\
(7.39 \mathrm{e}-06)\end{array}$ & $\begin{array}{c}3.35 \mathrm{e}-06 \\
(7.81 \mathrm{e}-06)\end{array}$ & $\begin{array}{c}2.56 \mathrm{e}-05^{* * *} \\
(8.41 \mathrm{e}-06)\end{array}$ & $\begin{array}{c}2.83 \mathrm{e}-05^{* * *} \\
(7.18 \mathrm{e}-06)\end{array}$ & $\begin{array}{c}2.96 \mathrm{e}-05^{* * *} \\
(6.81 \mathrm{e}-06)\end{array}$ \\
\hline Year ${ }^{*}$ Poor Relief p. $C$. & $\begin{array}{c}0.000195^{* * *} \\
(3.87 \mathrm{e}-05)\end{array}$ & $\begin{array}{c}0.000166^{* * *} \\
(3.58 \mathrm{e}-05)\end{array}$ & $\begin{array}{c}0.000139 * * * \\
(3.47 \mathrm{e}-05)\end{array}$ & $\begin{array}{c}0.000151^{* * *} \\
(4.66 \mathrm{e}-05)\end{array}$ & $\begin{array}{c}0.000133^{* * *} \\
(3.86 \mathrm{e}-05)\end{array}$ & $\begin{array}{c}4.91 \mathrm{e}-05 \\
(3.68 \mathrm{e}-05)\end{array}$ \\
\hline Population & $\begin{array}{c}6.01 \mathrm{e}-06^{* *} \\
(2.94 \mathrm{e}-06)\end{array}$ & $\begin{array}{c}6.07 \mathrm{e}-06^{* *} \\
(2.86 \mathrm{e}-06)\end{array}$ & $\begin{array}{c}1.38 \mathrm{e}-05^{* * *} \\
(4.35 \mathrm{e}-06)\end{array}$ & $\begin{array}{c}1.25 \mathrm{e}-06 \\
(4.29 \mathrm{e}-06)\end{array}$ & $\begin{array}{c}5.30 \mathrm{e}-07 \\
(4.00 \mathrm{e}-06)\end{array}$ & $\begin{array}{c}1.16 \mathrm{e}-05^{* * *} \\
(4.11 \mathrm{e}-06)\end{array}$ \\
\hline Wheat Price & & & & $\begin{array}{c}-0.000448^{* *} \\
(0.000172)\end{array}$ & $\begin{array}{c}-0.000481^{* * *} \\
(0.000151)\end{array}$ & $\begin{array}{c}-0.000750^{* * *} \\
(0.000133)\end{array}$ \\
\hline Wealth & & & & $\begin{array}{c}-6.64 \mathrm{e}-05^{* *} \\
(3.26 \mathrm{e}-05)\end{array}$ & $\begin{array}{c}-6.85 \mathrm{e}-05^{* *} \\
(3.04 \mathrm{e}-05)\end{array}$ & $\begin{array}{l}-4.44 \mathrm{e}-05 \\
(4.53 \mathrm{e}-05)\end{array}$ \\
\hline Market Dependency & & & & $\begin{array}{l}0.00237^{* * *} \\
(0.000675)\end{array}$ & $\begin{array}{l}0.00209^{* * *} \\
(0.000711)\end{array}$ & $\begin{array}{c}0.000542 \\
(0.000742)\end{array}$ \\
\hline Usable Land & & & & $\begin{array}{c}1.29 \mathrm{e}-07 \\
(9.16 \mathrm{e}-07)\end{array}$ & $\begin{array}{c}1.26 \mathrm{e}-06 \\
(9.90 \mathrm{e}-07)\end{array}$ & \\
\hline London Distance & & & & $\begin{array}{c}6.01 \mathrm{e}-06 \\
(4.15 \mathrm{e}-06)\end{array}$ & $\begin{array}{l}-7.07 \mathrm{e}-06 \\
(6.86 \mathrm{e}-06)\end{array}$ & \\
\hline Black Death Impact & & & & $\begin{array}{l}2.05 \mathrm{e}-05^{* *} \\
(7.56 \mathrm{e}-06)\end{array}$ & $\begin{array}{c}3.87 \mathrm{e}-05^{* * *} \\
(9.11 \mathrm{e}-06)\end{array}$ & \\
\hline Observations & 233 & 233 & 233 & 230 & 230 & 230 \\
\hline R-squared & 0.422 & 0.430 & 0.709 & 0.499 & 0.533 & 0.751 \\
\hline
\end{tabular}

No fixed effects included in columns (1) and (4). Region fixed effects included in columns (2) and (5).

County fixed effects included in columns(3) and (6). Standard errors clustered by county in parentheses. *** $\mathrm{p}<0.01,{ }^{* *} \mathrm{p}<0.05,{ }^{*} \mathrm{p}<0.1$ 
Table 4: Poor Relief \& Pop. Growth-Natural log Population Growth

\begin{tabular}{|c|c|c|c|c|c|c|}
\hline VARIABLES & $\begin{array}{c}\text { (1) } \\
\text { OLS } \\
\ln (\text { Pop. Grow. }) \\
\end{array}$ & $\begin{array}{c}(2) \\
\text { OLS } \\
\ln (\text { Pop. Grow. }) \\
\end{array}$ & $\begin{array}{c}\text { (3) } \\
\text { OLS } \\
\ln (\text { Pop. } \quad \text { Grow. }) \\
\end{array}$ & $\begin{array}{c}\text { (4) } \\
\text { OLS } \\
\ln (\text { Pop. Grow. }) \\
\end{array}$ & $\begin{array}{c}\text { (5) } \\
\text { OLS } \\
\ln (\text { Pop. } \quad \text { Grow. }) \\
\end{array}$ & $\begin{array}{c}\text { (6) } \\
\text { OLS } \\
\ln (\text { Pop. Grow. })\end{array}$ \\
\hline Poor Relief per Cap. & $\begin{array}{c}-0.349^{* * *} \\
(0.0701)\end{array}$ & $\begin{array}{c}-0.296^{* * *} \\
(0.0649)\end{array}$ & $\begin{array}{c}-0.246^{* * *} \\
(0.0622)\end{array}$ & $\begin{array}{c}-0.266^{* * *} \\
(0.0847)\end{array}$ & $\begin{array}{c}-0.233^{* * *} \\
(0.0700)\end{array}$ & $\begin{array}{l}-0.0803 \\
(0.0664)\end{array}$ \\
\hline Year & $\begin{array}{c}1.01 \mathrm{e}-05 \\
(7.42 \mathrm{e}-06)\end{array}$ & $\begin{array}{c}1.11 \mathrm{e}-05 \\
(7.35 \mathrm{e}-06)\end{array}$ & $\begin{array}{c}3.49 \mathrm{e}-06 \\
(7.77 \mathrm{e}-06)\end{array}$ & $\begin{array}{c}2.55 \mathrm{e}-05^{* * *} \\
(8.37 \mathrm{e}-06)\end{array}$ & $\begin{array}{c}2.82 \mathrm{e}-05^{* * *} \\
(7.14 \mathrm{e}-06)\end{array}$ & $\begin{array}{c}2.95 \mathrm{e}-05^{* * *} \\
(6.78 \mathrm{e}-06)\end{array}$ \\
\hline Year* Poor Rel. p. C. & $\begin{array}{c}0.000193^{* * *} \\
(3.85 \mathrm{e}-05)\end{array}$ & $\begin{array}{c}0.000165^{* * *} \\
(3.56 \mathrm{e}-05)\end{array}$ & $\begin{array}{c}0.000137^{* * *} \\
(3.44 \mathrm{e}-05)\end{array}$ & $\begin{array}{c}0.000149^{* * *} \\
(4.63 \mathrm{e}-05)\end{array}$ & $\begin{array}{c}0.000131^{* * *} \\
(3.83 \mathrm{e}-05)\end{array}$ & $\begin{array}{c}4.82 \mathrm{e}-05 \\
(3.66 \mathrm{e}-05)\end{array}$ \\
\hline Population & $\begin{array}{c}5.96 \mathrm{e}-06^{* *} \\
(2.91 \mathrm{e}-06)\end{array}$ & $\begin{array}{c}6.02 \mathrm{e}-06^{* *} \\
(2.83 \mathrm{e}-06)\end{array}$ & $\begin{array}{c}1.36 \mathrm{e}-05^{* * *} \\
(4.32 \mathrm{e}-06)\end{array}$ & $\begin{array}{c}1.22 \mathrm{e}-06 \\
(4.25 \mathrm{e}-06)\end{array}$ & $\begin{array}{c}5.01 \mathrm{e}-07 \\
(3.96 \mathrm{e}-06)\end{array}$ & $\begin{array}{c}1.15 \mathrm{e}-05^{* * *} \\
(4.07 \mathrm{e}-06)\end{array}$ \\
\hline Wheat Price & & & & $\begin{array}{c}-0.000445^{* *} \\
(0.000170)\end{array}$ & $\begin{array}{c}-0.000478^{* * *} \\
(0.000150)\end{array}$ & $\begin{array}{c}-0.000745^{* * *} \\
(0.000133)\end{array}$ \\
\hline Wealth & & & & $\begin{array}{c}-6.60 \mathrm{e}-05^{* *} \\
(3.24 \mathrm{e}-05)\end{array}$ & $\begin{array}{c}-6.81 \mathrm{e}-05^{* *} \\
(3.02 \mathrm{e}-05)\end{array}$ & $\begin{array}{l}-4.38 \mathrm{e}-05 \\
(4.51 \mathrm{e}-05)\end{array}$ \\
\hline Market Dependency & & & & $\begin{array}{c}0.00236^{* * *} \\
(0.000673)\end{array}$ & $\begin{array}{l}0.00209^{* * *} \\
(0.000709)\end{array}$ & $\begin{array}{c}0.000544 \\
(0.000738)\end{array}$ \\
\hline Usable Land & & & & $\begin{array}{c}1.32 \mathrm{e}-07 \\
(9.09 \mathrm{e}-07)\end{array}$ & $\begin{array}{c}1.25 \mathrm{e}-06 \\
(9.83 \mathrm{e}-07)\end{array}$ & \\
\hline London Distance & & & & $\begin{array}{c}5.98 \mathrm{e}-06 \\
(4.13 \mathrm{e}-06)\end{array}$ & $\begin{array}{l}-6.99 \mathrm{e}-06 \\
(6.81 \mathrm{e}-06)\end{array}$ & \\
\hline Black Death Im. & & & & $\begin{array}{c}2.04 \mathrm{e}-05^{* * *} \\
(7.52 \mathrm{e}-06)\end{array}$ & $\begin{array}{c}3.85 \mathrm{e}-05^{* * *} \\
(9.04 \mathrm{e}-06)\end{array}$ & \\
\hline Observations & 233 & 233 & 233 & 230 & 230 & 230 \\
\hline R-squared & 0.422 & 0.430 & 0.709 & 0.499 & 0.533 & 0.751 \\
\hline
\end{tabular}

No fixed effects included in columns (1) and (4). Region fixed effects included in columns (2) and (5).

County fixed effects included in columns(3) and (6). Standard errors clustered by county in parentheses. $* * * \mathrm{p}<0.01,{ }^{* *} \mathrm{p}<0.05,{ }^{*} \mathrm{p}<0.1$ 
Table 5: Role of Aggregate Poor Relief in Population Growth

\begin{tabular}{|c|c|c|c|c|c|c|}
\hline VARIABLES & $\begin{array}{c}\text { (1) } \\
\text { OLS } \\
\text { Pop. Growth }\end{array}$ & $\begin{array}{c}\text { (2) } \\
\text { OLS } \\
\text { Pop. Growth } \\
\end{array}$ & $\begin{array}{c}\text { (3) } \\
\text { OLS } \\
\text { Pop. Growth } \\
\end{array}$ & $\begin{array}{c}\text { (4) } \\
\text { OLS } \\
\text { Pop. Growth } \\
\end{array}$ & $\begin{array}{c}\text { (5) } \\
\text { OLS } \\
\text { Pop. Growth } \\
\end{array}$ & $\begin{array}{c}\text { (6) } \\
\text { OLS } \\
\text { Pop. Growth } \\
\end{array}$ \\
\hline Poor Relief & $\begin{array}{c}-0.00126^{* * *} \\
(0.000300)\end{array}$ & $\begin{array}{c}-0.00116^{* * *} \\
(0.000270)\end{array}$ & $\begin{array}{c}-0.000717^{* * *} \\
(0.000256)\end{array}$ & $\begin{array}{c}-0.00128^{* * *} \\
(0.000400)\end{array}$ & $\begin{array}{c}-0.00124^{* * *} \\
(0.000322)\end{array}$ & $\begin{array}{c}-0.000538^{* * *} \\
(0.000187)\end{array}$ \\
\hline Year & $\begin{array}{c}2.99 \mathrm{e}-05^{* * *} \\
(5.32 \mathrm{e}-06)\end{array}$ & $\begin{array}{c}3.01 \mathrm{e}-05^{* * *} \\
(5.25 \mathrm{e}-06)\end{array}$ & $\begin{array}{c}3.10 \mathrm{e}-05^{* * *} \\
(4.92 \mathrm{e}-06)\end{array}$ & $\begin{array}{c}3.93 \mathrm{e}-05^{* * *} \\
(7.77 \mathrm{e}-06)\end{array}$ & $\begin{array}{c}4.01 \mathrm{e}-05^{* * *} \\
(6.61 \mathrm{e}-06)\end{array}$ & $\begin{array}{c}4.41 \mathrm{e}-05^{* * *} \\
(3.99 \mathrm{e}-06)\end{array}$ \\
\hline Year ${ }^{*}$ Poor Relief & $\begin{array}{c}6.98 \mathrm{e}-07^{* * *} \\
(1.65 \mathrm{e}-07)\end{array}$ & $\begin{array}{c}6.43 \mathrm{e}-07^{* * *} \\
(1.48 \mathrm{e}-07)\end{array}$ & $\begin{array}{c}3.98 \mathrm{e}-07^{* * *} \\
(1.42 \mathrm{e}-07)\end{array}$ & $\begin{array}{c}7.06 \mathrm{e}-07^{* * *} \\
(2.20 \mathrm{e}-07)\end{array}$ & $\begin{array}{c}6.85 \mathrm{e}-07^{* * * *} \\
(1.77 \mathrm{e}-07)\end{array}$ & $\begin{array}{c}3.01 \mathrm{e}-07^{* * *} \\
(1.04 \mathrm{e}-07)\end{array}$ \\
\hline Population & $\begin{array}{l}9.20 \mathrm{e}-06^{* *} \\
(4.15 \mathrm{e}-06)\end{array}$ & $\begin{array}{c}8.70 \mathrm{e}-06^{* *} \\
(3.78 \mathrm{e}-06)\end{array}$ & $\begin{array}{c}7.67 \mathrm{e}-06 \\
(5.27 \mathrm{e}-06)\end{array}$ & $\begin{array}{c}3.82 \mathrm{e}-06 \\
(5.76 \mathrm{e}-06)\end{array}$ & $\begin{array}{c}2.67 \mathrm{e}-06 \\
(4.15 \mathrm{e}-06)\end{array}$ & $\begin{array}{c}4.40 \mathrm{e}-06 \\
(7.09 \mathrm{e}-06)\end{array}$ \\
\hline Wheat Price & & & & $\begin{array}{c}-0.000213^{* *} \\
(9.46 \mathrm{e}-05)\end{array}$ & $\begin{array}{c}-0.000213^{* * *} \\
(6.94 \mathrm{e}-05)\end{array}$ & $\begin{array}{c}-0.000325^{* * *} \\
(5.88 \mathrm{e}-05)\end{array}$ \\
\hline Wealth & & & & $\begin{array}{l}-5.29 \mathrm{e}-05 \\
(3.17 \mathrm{e}-05)\end{array}$ & $\begin{array}{r}-5.78 \mathrm{e}-05^{*} \\
(2.92 \mathrm{e}-05)\end{array}$ & $\begin{array}{l}-2.92 \mathrm{e}-05 \\
(6.53 \mathrm{e}-05)\end{array}$ \\
\hline Market Dependency & & & & $\begin{array}{c}0.00244^{* * *} \\
(0.000751)\end{array}$ & $\begin{array}{l}0.00217^{* *} \\
(0.000802)\end{array}$ & $\begin{array}{c}0.000469 \\
(0.000803)\end{array}$ \\
\hline Usable Land & & & & $\begin{array}{c}2.78 \mathrm{e}-07 \\
(8.02 \mathrm{e}-07)\end{array}$ & $\begin{array}{l}1.43 \mathrm{e}-06^{*} \\
(8.47 \mathrm{e}-07)\end{array}$ & \\
\hline London Distance & & & & $\begin{array}{c}1.52 \mathrm{e}-06 \\
(3.67 \mathrm{e}-06)\end{array}$ & $\begin{array}{c}-1.15 \mathrm{e}-05^{*} \\
(6.26 \mathrm{e}-06)\end{array}$ & \\
\hline Black Death Impact & & & & $\begin{array}{c}2.13 \mathrm{e}-05^{* *} \\
(8.45 \mathrm{e}-06)\end{array}$ & $\begin{array}{c}3.91 \mathrm{e}-05^{* * *} \\
(8.75 \mathrm{e}-06)\end{array}$ & \\
\hline Observations & 233 & 233 & 233 & 230 & 230 & 230 \\
\hline R-squared & 0.431 & 0.436 & 0.680 & 0.499 & 0.531 & 0.693 \\
\hline
\end{tabular}

No fixed effects included in columns (1) and (4). Region fixed effects included in columns (2) and (5).

County fixed effects included in columns(3) and (6). Standard errors clustered by county in parentheses.

$$
\text { *** } \mathrm{p}<0.01,{ }^{* *} \mathrm{p}<0.05,{ }^{*} \mathrm{p}<0.1
$$


Table 6: Instrumental-Variable Estimates of Poor Relief \& Population Growth

\begin{tabular}{|c|c|c|c|c|c|c|}
\hline VARIABLES & $\begin{array}{c}\text { (1) } \\
\text { Poor Rel. p. C. }\end{array}$ & $\begin{array}{c}(2) \\
Y r .{ }^{*} \text { Poor R. } p . C .\end{array}$ & $\begin{array}{c}\text { (3) } \\
\text { Pop. Growth }\end{array}$ & $\begin{array}{c}(4) \\
\text { Poor Rel. p. C. }\end{array}$ & $\begin{array}{c}(5) \\
Y r .{ }^{*} \text { Poor R. p. C. }\end{array}$ & $\begin{array}{c}\text { (6) } \\
\text { Pop. Growth }\end{array}$ \\
\hline Poor Re $\widehat{\text { lief per Capita }}$ & & & $\begin{array}{c}-0.425^{* * *} \\
(0.091)\end{array}$ & & & $\begin{array}{c}-0.402^{* * *} \\
(0.0890)\end{array}$ \\
\hline Year & $\begin{array}{l}.00097^{* *} \\
(0.00047)\end{array}$ & $\begin{array}{l}1.844^{* *} \\
(0.862)\end{array}$ & & $\begin{array}{c}0.00097^{* *} \\
(0.00048)\end{array}$ & $\begin{array}{l}1.907^{* *} \\
(0.855)\end{array}$ & \\
\hline Year * Poor $\widehat{R e l .}$ per $C$. & & & $\begin{array}{c}0.000238^{* * *} \\
(0.000049)\end{array}$ & & & $\begin{array}{l}0.00023^{* * *} \\
(0.000047)\end{array}$ \\
\hline Black Death Impact & $\begin{array}{c}.0161^{* * *} \\
(.0041)\end{array}$ & $\begin{array}{c}32.02^{* * *} \\
(5.895)\end{array}$ & & $\begin{array}{c}0.0161^{* * *} \\
(0.0041)\end{array}$ & $\begin{array}{c}29.62^{* * *} \\
(7.507)\end{array}$ & \\
\hline Usable Land & $\begin{array}{c}-0.0027^{* * *} \\
(0.00064)\end{array}$ & $\begin{array}{c}-4.523^{* * *} \\
(1.132)\end{array}$ & & $\begin{array}{c}-0.0027^{* * *} \\
(0.00064)\end{array}$ & $\begin{array}{c}-4.897^{* * *} \\
(1.171)\end{array}$ & \\
\hline Observations & 230 & 230 & 230 & 226 & 226 & 226 \\
\hline R-squared & 0.427 & 0.425 & 0.618 & 0.432 & 0.431 & 0.650 \\
\hline K-P Wald F statistic & & 8.42 & & & 7.31 & \\
\hline Hansen J statistic & & 1.983 & p-val: .1590 & & 1.921 & p-val: .1657 \\
\hline A-R Wald F statistic & & 36.25 & p-val: .0000 & & 26.91 & p-val: .0000 \\
\hline S-W s statistic & & 49.98 & p-val: .0000 & & 37.71 & p-val: .0000 \\
\hline
\end{tabular}

OLS regression results reported in all columns. No fixed effects in columns (1) and (4).

County fixed effects included in columns (2), (3), (5) and (6) but not shown. Robust errors in parentheses. $* * * \mathrm{p}<0.01, * * \mathrm{p}<0.05, * \mathrm{p}<0.1$ 
Table 7: Role of Poor Relief in Food Riots by County

\begin{tabular}{|c|c|c|c|c|c|c|c|c|}
\hline VARIABLES & $\begin{array}{c}\text { OLS } \\
\text { OLiots/Year } \\
\end{array}$ & $\begin{array}{c}\text { OLS } \\
\text { Riots/Year } \\
\end{array}$ & $\begin{array}{c}\text { OLS } \\
\text { Riots } / \text { Year } \\
\end{array}$ & $\begin{array}{c}\text { OLS } \\
\text { OLs } / \text { Year } \\
\text { Riot }\end{array}$ & $\begin{array}{c}(5) \\
\text { Poisson } \\
\text { Riots/Year }\end{array}$ & $\begin{array}{c}\text { (6) } \\
\text { Poisson } \\
\text { Riots/Year }\end{array}$ & $\begin{array}{c}(7) \\
\text { Poisson } \\
\text { Riots/Year }\end{array}$ & $\begin{array}{c}(8) \\
\text { Poisson } \\
\text { Riots/Year }\end{array}$ \\
\hline Poor Relief p. Cap. & $\begin{array}{c}-1.188^{* *} \\
(0.169)\end{array}$ & $\begin{array}{c}-1.386^{* *} \\
(0.215)\end{array}$ & $\begin{array}{c}-1.405^{*} \\
(0.371)\end{array}$ & $\begin{array}{l}-0.663 \\
(0.393)\end{array}$ & $\begin{array}{c}-1.663^{* * *} \\
(0.271)\end{array}$ & $\begin{array}{c}-1.851^{* * *} \\
(0.351)\end{array}$ & $\begin{array}{c}-1.909^{* * *} \\
(0.497)\end{array}$ & $\begin{array}{c}-1.138^{*} \\
(0.632)\end{array}$ \\
\hline Food Riots $_{t-1}$ & & $\begin{array}{c}-0.133^{* *} \\
(0.0242)\end{array}$ & $\begin{array}{c}-0.135^{* * *} \\
(0.00949)\end{array}$ & $\begin{array}{c}-0.168^{* *} \\
(0.0202)\end{array}$ & & $\begin{array}{c}-0.197^{* *} \\
(0.0770)\end{array}$ & $\begin{array}{c}-0.196^{* * *} \\
(0.0689)\end{array}$ & $\begin{array}{c}-0.247^{* * *} \\
(0.0758)\end{array}$ \\
\hline Population & & $\begin{array}{c}0.00213^{* *} \\
(0.000446)\end{array}$ & $\begin{array}{c}0.00230^{*} \\
(0.000689)\end{array}$ & $\begin{array}{c}0.00187^{* *} \\
(0.000229)\end{array}$ & & $\begin{array}{c}0.00225^{* * *} \\
(0.000630)\end{array}$ & $\begin{array}{c}0.00250^{* * *} \\
(0.000791)\end{array}$ & $\begin{array}{c}0.00176^{* * *} \\
(0.000371)\end{array}$ \\
\hline Wealth & & & $\begin{array}{c}0.0129 \\
(0.0306)\end{array}$ & $\begin{array}{l}-0.00358 \\
(0.0237)\end{array}$ & & & $\begin{array}{c}0.0138 \\
(0.0356)\end{array}$ & $\begin{array}{c}-0.00629 \\
(0.0288)\end{array}$ \\
\hline Market Depend. & & & $\begin{array}{c}0.333 \\
(0.261)\end{array}$ & $\begin{array}{c}0.426 \\
(0.264)\end{array}$ & & & $\begin{array}{l}0.255^{*} \\
(0.141)\end{array}$ & $\begin{array}{c}0.416 \\
(0.302)\end{array}$ \\
\hline Law Enforcement & & & & $\begin{array}{c}-0.0565 \\
(0.0348)\end{array}$ & & & & $\begin{array}{l}-0.0374 \\
(0.0435)\end{array}$ \\
\hline London Distance & & & & $\begin{array}{c}0.00492 \\
(0.00269)\end{array}$ & & & & $\begin{array}{c}0.00465^{* * *} \\
(0.00164)\end{array}$ \\
\hline Region FEs & Yes & Yes & Yes & Yes & Yes & Yes & Yes & Yes \\
\hline Year FEs & No & No & No & No & No & No & No & No \\
\hline Observations & 233 & 233 & 230 & 230 & 233 & 233 & 230 & 230 \\
\hline R-squared & 0.036 & 0.076 & 0.086 & 0.116 & & & & \\
\hline
\end{tabular}


Table 8: Role of Poor Relief in Food Riots with County and Year Fixed Effects

\begin{tabular}{|c|c|c|c|c|c|c|}
\hline VARIABLES & $\begin{array}{c}\text { OLS } \\
\text { Riots per Year }\end{array}$ & $\begin{array}{c}\text { OLS } \\
\text { Riots per Year }\end{array}$ & $\begin{array}{c}\text { OLS } \\
\text { Riots per Year } \\
\end{array}$ & $\begin{array}{c}\text { OLS } \\
\text { OLiots per Year }\end{array}$ & $\begin{array}{c}\text { (5) } \\
\text { GLM } \\
\text { Riots per Year }\end{array}$ & $\begin{array}{c}(6) \\
\text { Poisson } \\
\text { Riots per Year }\end{array}$ \\
\hline Poor Relief per Capita & $\begin{array}{c}-0.131 \\
(1.083)\end{array}$ & $\begin{array}{c}0.478 \\
(0.474)\end{array}$ & $\begin{array}{l}-1.787 \\
(0.989)\end{array}$ & $\begin{array}{c}-0.175 \\
(1.188)\end{array}$ & $\begin{array}{c}-3.517^{* *} \\
(1.397)\end{array}$ & $\begin{array}{c}-2.881^{* * * *} \\
(1.059)\end{array}$ \\
\hline Food Riots $s_{t-1}$ & $\begin{array}{l}-0.0284 \\
(0.0570)\end{array}$ & $\begin{array}{l}1.713^{* *} \\
(0.254)\end{array}$ & $\begin{array}{l}-0.0726 \\
(0.0559)\end{array}$ & $\begin{array}{c}-0.393^{* * *} \\
(0.0967)\end{array}$ & $\begin{array}{c}-0.123^{* *} \\
(0.0623)\end{array}$ & $\begin{array}{c}-0.144^{* *} \\
(0.0574)\end{array}$ \\
\hline Population & $\begin{array}{l}0.00135^{* *} \\
(0.000173)\end{array}$ & $\begin{array}{c}0.00334 \\
(0.00269)\end{array}$ & $\begin{array}{c}0.00111 \\
(0.000564)\end{array}$ & $\begin{array}{c}0.00776^{* *} \\
(0.00328)\end{array}$ & $\begin{array}{c}0.00717^{* *} \\
(0.00302)\end{array}$ & $\begin{array}{c}0.0120^{* * *} \\
(0.00457)\end{array}$ \\
\hline Wealth & $\begin{array}{c}-0.00274 \\
(0.0155)\end{array}$ & $\begin{array}{c}0.0120^{*} \\
(0.00308)\end{array}$ & $\begin{array}{c}-0.00278 \\
(0.0218)\end{array}$ & $\begin{array}{c}0.0269 \\
(0.0240)\end{array}$ & $\begin{array}{c}0.0933^{*} \\
(0.0494)\end{array}$ & $\begin{array}{c}0.127^{*} \\
(0.0648)\end{array}$ \\
\hline Market Dependency & $\begin{array}{c}0.108 \\
(0.184)\end{array}$ & $\begin{array}{l}-0.706 \\
(1.150)\end{array}$ & $\begin{array}{c}-0.00577 \\
(0.181)\end{array}$ & $\begin{array}{c}-1.111^{*} \\
(0.654)\end{array}$ & $\begin{array}{c}0.00907 \\
(0.456)\end{array}$ & $\begin{array}{l}-0.286 \\
(0.427)\end{array}$ \\
\hline Law Enforcement & $\begin{array}{l}-0.0463 \\
(0.0382)\end{array}$ & $\begin{array}{c}-0.169 \\
(0.0647)\end{array}$ & $\begin{array}{c}0.0807^{* * *} \\
(0.00518)\end{array}$ & $\begin{array}{l}0.00828 \\
(0.0625)\end{array}$ & $\begin{array}{c}0.0741 \\
(0.0825)\end{array}$ & $\begin{array}{l}-0.0197 \\
(0.0797)\end{array}$ \\
\hline London Distance & $\begin{array}{c}0.00495 \\
(0.00313)\end{array}$ & $\begin{array}{l}-0.0140^{*} \\
(0.00358)\end{array}$ & $\begin{array}{c}0.00650 \\
(0.00341)\end{array}$ & & & \\
\hline Region FEs & Yes & Yes & Yes & No & No & No \\
\hline County FEs & No & No & No & Yes & Yes & Yes \\
\hline Year FEs & Yes & n.a. & Yes & Yes & Yes & Yes \\
\hline Observations & 230 & 39 & 191 & 191 & 191 & 191 \\
\hline R-squared & 0.313 & 0.296 & 0.369 & 0.590 & & \\
\hline
\end{tabular}


Table 9: Poor Relief \& Food Riots-Incidence Models \& Est. Conditional on Incidence

\begin{tabular}{|c|c|c|c|c|c|c|}
\hline VARIABLES & $\begin{array}{c}\text { (1) } \\
\text { OLS } \\
\mathrm{I}(\text { Riots } / \text { Year }) \\
\end{array}$ & $\begin{array}{c}(2) \\
\text { OLS } \\
\mathrm{I}(\text { Riots } / \text { Year }) \\
\end{array}$ & $\begin{array}{c}3) \\
\text { OLS } \\
\mathrm{I}(\text { Riots } / Y e a r) \\
\end{array}$ & $\begin{array}{c}\text { OLS } \\
\text { OLS } \\
\text { Riots/Year }\end{array}$ & $\begin{array}{c}\text { OLS } \\
\text { Riots/Year }\end{array}$ & $\begin{array}{c}(6) \\
\text { OLS } \\
\text { Riots/Year } \\
\end{array}$ \\
\hline Poor Relief per Capita & $\begin{array}{c}-1.149^{* * *} \\
(0.320)\end{array}$ & $\begin{array}{c}-1.239^{* * *} \\
(0.313)\end{array}$ & $\begin{array}{c}-1.276^{* * *} \\
(0.359)\end{array}$ & $\begin{array}{c}-0.0212 \\
(2.015)\end{array}$ & $\begin{array}{c}0.185 \\
(1.674)\end{array}$ & $\begin{array}{c}0.959 \\
(2.657)\end{array}$ \\
\hline $\mathrm{I}\left(\right.$ Riots per Year $\left._{t-1}\right)$ & & $\begin{array}{c}-0.162^{* *} \\
(0.0712)\end{array}$ & $\begin{array}{c}-0.167^{* *} \\
(0.0795)\end{array}$ & & & \\
\hline Riots per Year $_{t-1}$ & & & & & $\begin{array}{c}-0.389^{* * *} \\
(0.109)\end{array}$ & $\begin{array}{c}-0.436^{* * *} \\
(0.118)\end{array}$ \\
\hline Population & & $\begin{array}{c}3.79 \mathrm{e}-05 \\
(0.000295)\end{array}$ & $\begin{array}{c}-0.000342 \\
(0.000910)\end{array}$ & & $\begin{array}{c}0.00669^{* *} \\
(0.00291)\end{array}$ & $\begin{array}{c}0.0110^{* * *} \\
(0.00354)\end{array}$ \\
\hline Wealth & & & $\begin{array}{c}-0.00554 \\
(0.0127)\end{array}$ & & & $\begin{array}{c}0.0675 \\
(0.0409)\end{array}$ \\
\hline Market Dependency & & & $\begin{array}{c}0.140 \\
(0.164)\end{array}$ & & & $\begin{array}{c}-2.200 \\
(1.467)\end{array}$ \\
\hline Law Enforcement & & & $\begin{array}{c}0.00653 \\
(0.0185)\end{array}$ & & & $\begin{array}{l}0.00244 \\
(0.0964)\end{array}$ \\
\hline County FEs & Yes & Yes & Yes & Yes & Yes & Yes \\
\hline Year FEs & Yes & Yes & Yes & Yes & Yes & Yes \\
\hline Observations & 194 & 194 & 191 & 122 & 122 & 120 \\
\hline R-squared & 0.528 & 0.541 & 0.550 & 0.558 & 0.614 & 0.639 \\
\hline
\end{tabular}

Standard errors clustered by county in parentheses.

Regressions in columns (4) through (6) are conditional on I(Riots/Year) $>0$.

$$
* * * \mathrm{p}<0.01,{ }^{* *} \mathrm{p}<0.05,{ }^{*} \mathrm{p}<0.1
$$


Table 10: Poor Relief \& Food Riots-Role of Fixed Effects \& Time Trends

\begin{tabular}{|c|c|c|c|c|c|c|c|}
\hline VARIABLES & $\begin{array}{c}1) \\
\mathrm{I}(\text { Riots } / Y r .)\end{array}$ & $\begin{array}{c}(2) \\
\mathrm{I}(\text { Riots } / Y r .)\end{array}$ & $\begin{array}{c}(3) \\
\mathrm{I}(\text { Riots/Yr. })\end{array}$ & $\begin{array}{c}(4) \\
\mathrm{I}(\text { Riots } / \text { Yr. })\end{array}$ & $\begin{array}{c}(5) \\
\mathrm{I}(\text { Riots } / Y r .)\end{array}$ & $\begin{array}{c}6) \\
\mathrm{I}(\text { Riots } / Y r .)\end{array}$ & $\begin{array}{c}(7) \\
\mathrm{I}(\text { Riots/Yr. })\end{array}$ \\
\hline Poor Relief / Cap. & $\begin{array}{c}-0.520^{* * *} \\
(0.163)\end{array}$ & $\begin{array}{c}-0.705^{* * *} \\
(0.230)\end{array}$ & $\begin{array}{c}-0.412^{*} \\
(0.244)\end{array}$ & $\begin{array}{l}-0.349 \\
(0.258)\end{array}$ & $\begin{array}{c}-0.822^{* *} \\
(0.393)\end{array}$ & $\begin{array}{c}-1.711^{* * *} \\
(0.365)\end{array}$ & $\begin{array}{c}-0.867^{* * *} \\
(0.294)\end{array}$ \\
\hline $\mathrm{I}\left(\right.$ Riots per Year $\left._{t-1}\right)$ & $\begin{array}{c}0.0455 \\
(0.0724)\end{array}$ & $\begin{array}{l}0.167^{* *} \\
(0.0737)\end{array}$ & $\begin{array}{c}-0.238^{* * *} \\
(0.0766)\end{array}$ & $\begin{array}{c}-0.237^{* * *} \\
(0.0773)\end{array}$ & $\begin{array}{c}-0.228^{* * *} \\
(0.0786)\end{array}$ & $\begin{array}{c}-0.219^{* * *} \\
(0.0703)\end{array}$ & $\begin{array}{l}0.162^{* *} \\
(0.0753)\end{array}$ \\
\hline Population & $\begin{array}{l}0.000449^{* *} \\
(0.000193)\end{array}$ & $\begin{array}{c}0.000569^{* * *} \\
(0.000202)\end{array}$ & $\begin{array}{l}-0.00126 \\
(0.00117)\end{array}$ & $\begin{array}{r}-0.000956 \\
(0.00105)\end{array}$ & $\begin{array}{c}-0.00102 \\
(0.000989)\end{array}$ & $\begin{array}{c}-0.00243^{* *} \\
(0.00118)\end{array}$ & $\begin{array}{c}0.0006066^{* * *} \\
(0.000214)\end{array}$ \\
\hline Wealth & $\begin{array}{c}-0.000719 \\
(0.00384)\end{array}$ & $\begin{array}{c}-0.000378 \\
(0.00387)\end{array}$ & $\begin{array}{l}-0.0165 \\
(0.0121)\end{array}$ & $\begin{array}{l}-0.0156 \\
(0.0123)\end{array}$ & $\begin{array}{l}-0.0133 \\
(0.0124)\end{array}$ & $\begin{array}{l}-0.0141 \\
(0.0123)\end{array}$ & $\begin{array}{l}0.000606 \\
(0.00398)\end{array}$ \\
\hline Market Depency. & $\begin{array}{c}0.310^{* *} \\
(0.119)\end{array}$ & $\begin{array}{c}0.163 \\
(0.109)\end{array}$ & $\begin{array}{c}0.253 \\
(0.194)\end{array}$ & $\begin{array}{c}0.256 \\
(0.195)\end{array}$ & $\begin{array}{c}0.252 \\
(0.184)\end{array}$ & $\begin{array}{c}0.226 \\
(0.176)\end{array}$ & $\begin{array}{c}0.172 \\
(0.106)\end{array}$ \\
\hline Year & & & & $\begin{array}{c}-0.000608 \\
(0.00113)\end{array}$ & $\begin{array}{l}-0.230 \\
(0.159)\end{array}$ & & \\
\hline Year $^{2}$ & & & & & $\begin{array}{c}6.65 \mathrm{e}-05 \\
(4.60 \mathrm{e}-05)\end{array}$ & & \\
\hline Wheat Price & & & & & & $\begin{array}{c}0.143^{* * *} \\
(0.0291)\end{array}$ & \\
\hline Region Code & & & & & & & $\begin{array}{c}0.0536 \\
(0.0546)\end{array}$ \\
\hline County FEs & No & Yes & No & Yes & Yes & Yes & No \\
\hline Year FEs & No & No & Yes & No & No & No & Yes \\
\hline Observations & 191 & 191 & 191 & 191 & 191 & 191 & 191 \\
\hline R-squared & 0.148 & 0.339 & 0.397 & 0.398 & 0.407 & 0.463 & 0.343 \\
\hline
\end{tabular}

OLS regression resultsreported in all columns. Standard errors clustered by county in parentheses.

Law Enforcement also included in all estimates but not significant in any specification.

$$
\text { *** } \mathrm{p}<0.01,{ }^{* *} \mathrm{p}<0.05,{ }^{*} \mathrm{p}<0.1
$$


Table 11: Role of Aggregate Poor Relief in Food Riots

\begin{tabular}{|c|c|c|c|c|c|c|}
\hline VARIABLES & $\begin{array}{c}(1) \\
\text { OLS } \\
\mathrm{I}(\text { Riots } / \text { Year })\end{array}$ & $\begin{array}{c}(2) \\
\text { OLS } \\
\mathrm{I}(\text { Riots } / \text { Year })\end{array}$ & $\begin{array}{c}\text { OLS } \\
\mathrm{I}(\text { Riots } / \text { Year })\end{array}$ & $\begin{array}{c}(4) \\
\text { Poisson } \\
\mathrm{I}(\text { Riots } / \text { Year })\end{array}$ & $\begin{array}{c}(5) \\
\text { Poisson } \\
\mathrm{I}(\text { Riots } / \text { Year })\end{array}$ & $\begin{array}{c}(6) \\
\text { Poisson } \\
\mathrm{I}(\text { Riots } / \text { Year })\end{array}$ \\
\hline Poor Relief & $\begin{array}{c}-0.00114^{* * *} \\
(0.000269)\end{array}$ & $\begin{array}{c}-0.00135^{* * *} \\
(0.000355)\end{array}$ & $\begin{array}{c}-0.000871^{* * *} \\
(0.000212)\end{array}$ & $\begin{array}{c}-0.00243^{* * *} \\
(0.000733)\end{array}$ & $\begin{array}{c}-0.00311^{* * *} \\
(0.00109)\end{array}$ & $\begin{array}{c}-0.00174^{* * *} \\
(0.000561)\end{array}$ \\
\hline $\mathrm{I}\left(\right.$ Riots per Year $\left._{t-1}\right)$ & & $\begin{array}{c}-0.115 \\
(0.0759)\end{array}$ & $\begin{array}{c}-0.118 \\
(0.0780)\end{array}$ & & $\begin{array}{l}-0.167 \\
(0.129)\end{array}$ & $\begin{array}{c}-0.194 \\
(0.141)\end{array}$ \\
\hline Population & & $\begin{array}{c}0.000277 \\
(0.000411)\end{array}$ & $\begin{array}{c}0.000456 \\
(0.000812)\end{array}$ & & $\begin{array}{c}0.00106 \\
(0.000658)\end{array}$ & $\begin{array}{c}0.00126 \\
(0.00145)\end{array}$ \\
\hline Wealth & & & $\begin{array}{l}-0.00551 \\
(0.00810)\end{array}$ & & & $\begin{array}{l}-0.0111 \\
(0.0154)\end{array}$ \\
\hline Market Dependency & & & $\begin{array}{l}0.0648 \\
(0.169)\end{array}$ & & & $\begin{array}{c}0.226 \\
(0.308)\end{array}$ \\
\hline Law Enforcement & & & $\begin{array}{l}-0.0250 \\
(0.0234)\end{array}$ & & & $\begin{array}{l}-0.0723 \\
(0.0630)\end{array}$ \\
\hline County FEs & Yes & Yes & Yes & Yes & Yes & Yes \\
\hline Year FEs & Yes & Yes & Yes & Yes & Yes & Yes \\
\hline Observations & 233 & 233 & 230 & 233 & 233 & 230 \\
\hline R-squared & 0.470 & 0.477 & 0.492 & & & \\
\hline
\end{tabular}


Table 12: Poor Relief \& Food Riots - Estimates based on Charlesworth Data

\begin{tabular}{|c|c|c|c|c|c|c|}
\hline VARIABLES & $\begin{array}{c}\text { (1) } \\
\text { OLS } \\
\text { Food Riots }\end{array}$ & $\begin{array}{c}(2) \\
\text { OLS } \\
\text { Food Riots }\end{array}$ & $\begin{array}{c}\text { (3) } \\
\text { OLS } \\
\text { Food Riots }\end{array}$ & $\begin{array}{c}(4) \\
\text { Poisson } \\
\text { Food Riots }\end{array}$ & $\begin{array}{c}(5) \\
\text { Poisson } \\
\text { Food Riots }\end{array}$ & $\begin{array}{c}(6) \\
\text { Poisson } \\
\text { Food Riots }\end{array}$ \\
\hline Poor Relief per Capita & $\begin{array}{l}-1.270 \\
(10.22)\end{array}$ & $\begin{array}{l}-5.909 \\
(9.351)\end{array}$ & $\begin{array}{c}-2.133 \\
(12.24)\end{array}$ & $\begin{array}{c}-3.182^{* *} \\
(1.398)\end{array}$ & $\begin{array}{c}-3.378^{* * *} \\
(1.138)\end{array}$ & $\begin{array}{c}-3.424^{* * *} \\
(1.136)\end{array}$ \\
\hline Food Riots Ri-1 & & $\begin{array}{c}-0.480^{* * *} \\
(0.0605)\end{array}$ & $\begin{array}{c}-0.444^{* * *} \\
(0.0934)\end{array}$ & & $\begin{array}{c}-0.0313^{* * *} \\
(0.00942)\end{array}$ & $\begin{array}{c}-0.0302^{* * *} \\
(0.00969)\end{array}$ \\
\hline Population & & $\begin{array}{c}0.0467^{* * * *} \\
(0.0145)\end{array}$ & $\begin{array}{c}0.0767^{* * *} * \\
(0.0251)\end{array}$ & & $\begin{array}{c}0.00436^{* * *} * \\
(0.00108)\end{array}$ & $\begin{array}{c}0.00479^{* *} \\
(0.00208)\end{array}$ \\
\hline Wealth & & & $\begin{array}{l}0.0683 \\
(0.268)\end{array}$ & & & $\begin{array}{c}0.0129 \\
(0.0207)\end{array}$ \\
\hline Market Dependency & & & $\begin{array}{c}6.912 \\
(7.515)\end{array}$ & & & $\begin{array}{c}0.509 \\
(0.518)\end{array}$ \\
\hline Law Enforcement & & & $\begin{array}{l}-1.281 \\
(0.815)\end{array}$ & & & $\begin{array}{c}0.00631 \\
(0.0632)\end{array}$ \\
\hline County FEs & Yes & Yes & Yes & Yes & Yes & Yes \\
\hline Year FEs & Yes & Yes & Yes & Yes & Yes & Yes \\
\hline Observations & 116 & 116 & 116 & 116 & 116 & 116 \\
\hline R-squared & 0.624 & 0.710 & 0.728 & & & \\
\hline
\end{tabular}


Table 13: Poor Relief \& Land \& Enclosure Unrests—with Charlesworth Data

\begin{tabular}{|c|c|c|c|c|c|c|}
\hline VARIABLES & $\begin{array}{c}(1) \\
\text { OLS } \\
\text { Land Protests } \\
\end{array}$ & $\begin{array}{c}(2) \\
\text { OLS } \\
\text { Land Protests } \\
\end{array}$ & $\begin{array}{c}\text { OLS } \\
\text { Land Protests } \\
\end{array}$ & $\begin{array}{c}(4) \\
\text { Poisson } \\
\text { Land Protests } \\
\end{array}$ & $\begin{array}{c}(5) \\
\text { Poisson } \\
\text { Land Protests }\end{array}$ & $\begin{array}{c}(6) \\
\text { Poisson } \\
\text { Land Protests } \\
\end{array}$ \\
\hline Poor Relief per Capita & $\begin{array}{c}0.548 \\
(1.348)\end{array}$ & $\begin{array}{c}0.714 \\
(1.368)\end{array}$ & $\begin{array}{l}0.0725 \\
(1.905)\end{array}$ & $\begin{array}{c}5.490^{* *} \\
(2.553)\end{array}$ & $\begin{array}{c}6.804^{* *} \\
(2.749)\end{array}$ & $\begin{array}{c}9.252^{* * *} \\
(3.563)\end{array}$ \\
\hline Land Protests $_{t-1}$ & & $\begin{array}{l}-0.177^{*} \\
(0.0988)\end{array}$ & $\begin{array}{l}-0.165 \\
(0.107)\end{array}$ & & $\begin{array}{l}-0.0753 \\
(0.0623)\end{array}$ & $\begin{array}{c}-0.122 \\
(0.0991)\end{array}$ \\
\hline Population & & $\begin{array}{c}0.00187 \\
(0.00141)\end{array}$ & $\begin{array}{c}0.00684^{*} \\
(0.00370)\end{array}$ & & $\begin{array}{l}0.00669^{*} \\
(0.00381)\end{array}$ & $\begin{array}{l}0.0228^{* *} \\
(0.00996)\end{array}$ \\
\hline Wealth & & & $\begin{array}{c}0.0567 \\
(0.0377)\end{array}$ & & & $\begin{array}{c}0.178^{* * *} \\
(0.0500)\end{array}$ \\
\hline Market Dependency & & & $\begin{array}{c}0.302 \\
(0.658)\end{array}$ & & & $\begin{array}{c}3.832^{* *} \\
(1.669)\end{array}$ \\
\hline Law Enforcement & & & $\begin{array}{l}-0.0739 \\
(0.0987)\end{array}$ & & & $\begin{array}{c}0.119 \\
(0.295)\end{array}$ \\
\hline County FEs & Yes & Yes & Yes & Yes & Yes & Yes \\
\hline Year FEs & Yes & Yes & Yes & Yes & Yes & Yes \\
\hline Observations & 116 & 116 & 116 & 116 & 116 & 116 \\
\hline R-squared & 0.574 & 0.604 & 0.630 & & & \\
\hline
\end{tabular}


Table 14: Poor Relief \& Food Riots-With Other Control Variables

\begin{tabular}{|c|c|c|c|c|c|c|}
\hline VARIABLES & $\begin{array}{c}1) \\
\mathrm{I}(\text { Riots } / \text { Year })\end{array}$ & $\begin{array}{c}(2) \\
\mathrm{I}(\text { Riots/Year })\end{array}$ & $\begin{array}{c}(3) \\
\mathrm{I}(\text { Riots/Year })\end{array}$ & $\begin{array}{c}(4) \\
\mathrm{I}(\text { Riots/Year }) \\
\end{array}$ & $\begin{array}{c}5) \\
\mathrm{I}(\text { Riots/Year }) \\
\end{array}$ & $\begin{array}{c}6) \\
\mathrm{I}(\text { Riots/Year })\end{array}$ \\
\hline Poor Relief per Capita & $\begin{array}{c}-0.700^{* * *} \\
(0.247)\end{array}$ & $\begin{array}{c}-0.618^{*} \\
(0.316)\end{array}$ & $\begin{array}{c}-0.756^{* *} \\
(0.303)\end{array}$ & $\begin{array}{c}-0.793^{* *} \\
(0.350)\end{array}$ & $\begin{array}{c}-1.426^{* *} \\
(0.661)\end{array}$ & $\begin{array}{c}-1.354^{* *} \\
(0.613)\end{array}$ \\
\hline $\mathrm{I}\left(\right.$ Riots per Year $\left._{t-1}\right)$ & $\begin{array}{c}0.244^{* * *} \\
(0.0793)\end{array}$ & $\begin{array}{l}0.233^{* * *} \\
(0.0791)\end{array}$ & $\begin{array}{l}0.152^{* *} \\
(0.0742)\end{array}$ & $\begin{array}{c}0.112 \\
(0.0742)\end{array}$ & $\begin{array}{l}0.246^{*} \\
(0.147)\end{array}$ & $\begin{array}{c}0.189 \\
(0.126)\end{array}$ \\
\hline Black Death Impact & $\begin{array}{l}0.00229^{*} \\
(0.00129)\end{array}$ & $\begin{array}{l}0.00231^{*} \\
(0.00130)\end{array}$ & $\begin{array}{c}0.00315^{* *} \\
(0.00136)\end{array}$ & $\begin{array}{l}0.00234^{*} \\
(0.00135)\end{array}$ & $\begin{array}{c}0.00432^{*} \\
(0.00237)\end{array}$ & $\begin{array}{l}0.00344^{*} \\
(0.00195)\end{array}$ \\
\hline Change in Wealth & & $\begin{array}{c}-0.0111 \\
(0.00840)\end{array}$ & $\begin{array}{l}-0.00788 \\
(0.00821)\end{array}$ & $\begin{array}{l}-0.00408 \\
(0.00739)\end{array}$ & $\begin{array}{r}-0.00506 \\
(0.0108)\end{array}$ & $\begin{array}{l}-0.00466 \\
(0.00937)\end{array}$ \\
\hline Change in Market Dependency & & $\begin{array}{l}-0.260^{*} \\
(0.149)\end{array}$ & $\begin{array}{l}-0.227 \\
(0.144)\end{array}$ & $\begin{array}{c}-0.277^{*} \\
(0.147)\end{array}$ & $\begin{array}{l}-0.362 \\
(0.234)\end{array}$ & $\begin{array}{l}-0.341 \\
(0.222)\end{array}$ \\
\hline London Distance & & & $\begin{array}{l}-0.00114^{*} \\
(0.000670)\end{array}$ & $\begin{array}{l}-0.00108^{*} \\
(0.000581)\end{array}$ & $\begin{array}{c}-0.00194^{*} \\
(0.00105)\end{array}$ & $\begin{array}{c}-0.00166^{* *} \\
(0.000788)\end{array}$ \\
\hline Usable Land & & & $\begin{array}{c}0.000293^{* * *} \\
(9.98 \mathrm{e}-05)\end{array}$ & $\begin{array}{c}0.000259^{* * *} \\
(9.41 \mathrm{e}-05)\end{array}$ & $\begin{array}{c}0.000504^{* * *} \\
(0.000191)\end{array}$ & $\begin{array}{c}0.000431^{* * *} \\
(0.000152)\end{array}$ \\
\hline Market Dependency & & & & $\begin{array}{l}0.187^{*} \\
(0.105)\end{array}$ & $\begin{array}{l}0.490^{*} \\
(0.252)\end{array}$ & $\begin{array}{c}0.474^{* *} \\
(0.219)\end{array}$ \\
\hline Law Enforcement & & & & $\begin{array}{c}0.00259 \\
(0.0158)\end{array}$ & $\begin{array}{c}0.0205 \\
(0.0339)\end{array}$ & $\begin{array}{c}0.0131 \\
(0.0270)\end{array}$ \\
\hline Region FEs & Yes & Yes & Yes & Yes & Yes & Yes \\
\hline Year FEs & Yes & Yes & Yes & Yes & Yes & Yes \\
\hline $\begin{array}{l}\text { Observations } \\
\text { R-squared }\end{array}$ & $\begin{array}{c}194 \\
0.298\end{array}$ & $\begin{array}{c}187 \\
0.316\end{array}$ & $\begin{array}{c}187 \\
0.357\end{array}$ & $\begin{array}{c}187 \\
0.373\end{array}$ & 187 & 187 \\
\hline
\end{tabular}

Results from OLS regressions in the first four columns, GLM within the binomial family in column (5) and Poisson regression estiamtes in column (6). Standard errors clustered by county in parentheses.

Population and Wealth Rank also included in all estimates but not significant in any specification.

$$
\text { *** } \mathrm{p}<0.01, * * \mathrm{p}<0.05, * \mathrm{p}<0.1
$$


Table 15: Poor Relief \& Food Riots-Dissecting the Time Trends

\begin{tabular}{|c|c|c|c|c|c|c|}
\hline VARIABLES & $\begin{array}{c}(1) \\
\mathrm{I}(\text { Riots } / Y r .)\end{array}$ & $\begin{array}{c}(2) \\
\mathrm{I}(\text { Riots } / Y r .)\end{array}$ & $\begin{array}{c}(3) \\
\mathrm{I}(\text { Riots/Yr. })\end{array}$ & $\begin{array}{c}(4) \\
\mathrm{I}(\text { Riots/Yr. })\end{array}$ & $\begin{array}{c}(5) \\
\mathrm{I}(\text { Riots/Yr. })\end{array}$ & $\begin{array}{c}(6) \\
\mathrm{I}(\text { Riots } / Y r .)\end{array}$ \\
\hline Poor Relief / Cap. & $\begin{array}{l}-25.88 \\
(16.11)\end{array}$ & $\begin{array}{l}-31.48^{*} \\
(16.20)\end{array}$ & $\begin{array}{c}-37.60^{* *} \\
(18.19)\end{array}$ & $\begin{array}{l}-15.94 \\
(11.12)\end{array}$ & $\begin{array}{l}-22.41^{*} \\
(12.91)\end{array}$ & $\begin{array}{l}-22.01^{*} \\
(12.52)\end{array}$ \\
\hline Year & $\begin{array}{c}-0.00476^{* *} \\
(0.00219)\end{array}$ & $\begin{array}{c}-0.00510^{* *} \\
(0.00223)\end{array}$ & $\begin{array}{c}-0.00591^{* *} \\
(0.00236)\end{array}$ & $\begin{array}{c}-0.00490^{* * *} \\
(0.00148)\end{array}$ & $\begin{array}{c}-0.00508^{* * *} \\
(0.00162)\end{array}$ & $\begin{array}{c}-0.00532^{* * *} \\
(0.00171)\end{array}$ \\
\hline Year * Poor Relief / Cap. & $\begin{array}{c}0.0138 \\
(0.00886)\end{array}$ & $\begin{array}{c}0.0169^{*} \\
(0.00891)\end{array}$ & $\begin{array}{c}0.0204^{* *} \\
(0.0100)\end{array}$ & $\begin{array}{c}0.00837 \\
(0.00615)\end{array}$ & $\begin{array}{c}0.0121^{*} \\
(0.00712)\end{array}$ & $\begin{array}{c}0.0118^{*} \\
(0.00691)\end{array}$ \\
\hline $\mathrm{I}\left(\right.$ Riots per Year $\left._{t-1}\right)$ & $\begin{array}{c}-0.208^{* * *} \\
(0.0637)\end{array}$ & $\begin{array}{c}-0.199^{* * *} \\
(0.0675)\end{array}$ & $\begin{array}{c}-0.207^{* * *} \\
(0.0678)\end{array}$ & $\begin{array}{c}0.0306 \\
(0.0694)\end{array}$ & $\begin{array}{c}0.0163 \\
(0.0657)\end{array}$ & $\begin{array}{c}0.0175 \\
(0.0734)\end{array}$ \\
\hline Population & $\begin{array}{c}-0.000981^{* *} \\
(0.000369)\end{array}$ & $\begin{array}{c}-0.00135^{* * *} \\
(0.000450)\end{array}$ & $\begin{array}{l}-0.000263 \\
(0.000806)\end{array}$ & $\begin{array}{c}0.000128 \\
(0.000207)\end{array}$ & $\begin{array}{c}0.000413 \\
(0.000261)\end{array}$ & $\begin{array}{c}0.000487^{*} \\
(0.000243)\end{array}$ \\
\hline Wheat Price & $\begin{array}{c}0.140^{* * *} \\
(0.0334)\end{array}$ & $\begin{array}{c}0.140^{* * *} \\
(0.0340)\end{array}$ & $\begin{array}{c}0.140^{* * *} \\
(0.0349)\end{array}$ & $\begin{array}{c}0.114^{* * *} \\
(0.0254)\end{array}$ & $\begin{array}{c}0.113^{* * *} \\
(0.0278)\end{array}$ & $\begin{array}{c}0.125^{* * *} \\
(0.0298)\end{array}$ \\
\hline Wealth & & $\begin{array}{c}-0.0129 \\
(0.00845)\end{array}$ & $\begin{array}{c}-0.0116 \\
(0.00802)\end{array}$ & & $\begin{array}{l}-8.83 \mathrm{e}-05 \\
(0.00396)\end{array}$ & $\begin{array}{c}0.00254 \\
(0.00396)\end{array}$ \\
\hline Market Dependency & & $\begin{array}{c}0.231 \\
(0.171)\end{array}$ & $\begin{array}{c}0.215 \\
(0.175)\end{array}$ & & $\begin{array}{c}0.276^{* * *} \\
(0.102)\end{array}$ & $\begin{array}{c}0.217^{* *} \\
(0.104)\end{array}$ \\
\hline Law Enforcement & & & $\begin{array}{l}-0.0289 \\
(0.0210)\end{array}$ & & $\begin{array}{c}-0.0317^{* *} \\
(0.0121)\end{array}$ & $\begin{array}{c}-0.0328^{* * *} \\
(0.0118)\end{array}$ \\
\hline Usable Land & & & & $\begin{array}{c}0.000209^{* *} \\
(9.78 \mathrm{e}-05)\end{array}$ & $\begin{array}{c}0.000232^{* * *} \\
(7.49 \mathrm{e}-05)\end{array}$ & $\begin{array}{c}0.000263^{* * *} \\
(7.19 \mathrm{e}-05)\end{array}$ \\
\hline London Distance & & & & $\begin{array}{l}-0.000715 \\
(0.000504)\end{array}$ & $\begin{array}{c}-0.00104^{* *} \\
(0.000428)\end{array}$ & $\begin{array}{r}-0.00135^{* * *} \\
(0.000437)\end{array}$ \\
\hline Black Death Impact & & & & $\begin{array}{l}0.00209^{* *} \\
(0.000890)\end{array}$ & $\begin{array}{l}0.00189^{* *} \\
(0.000819)\end{array}$ & $\begin{array}{r}0.00226^{* * *} \\
(0.000823)\end{array}$ \\
\hline Observations & 233 & 230 & 230 & 233 & 230 & 226 \\
\hline R-squared & 0.410 & 0.431 & 0.438 & 0.195 & 0.249 & 0.261 \\
\hline
\end{tabular}

OLS regression results reported in all columns. County fixed effects included in the first three regressions.

Region fixed effects included in the final three regressions. Change in Wealth and Change in Market Dep. included in all regressions but not shown. Standard errors clustered by county in parentheses.

*** $\mathrm{p}<0.01,{ }^{* *} \mathrm{p}<0.05,{ }^{*} \mathrm{p}<0.1$ 
Table 16: Simultaneous Equations Estimates of Poor Relief, Food Riots \& Innovations

\begin{tabular}{|c|c|c|c|c|c|c|}
\hline VARIABLES & $\begin{array}{c}\quad(1) \\
\text { Poor Rel. p. C. }\end{array}$ & $\begin{array}{c}(2) \\
Y r .{ }^{*} \text { Poor R. } p . C .\end{array}$ & $\begin{array}{c}\text { (3) } \\
\text { Riots/Year }\end{array}$ & $\begin{array}{c}\quad(4) \\
\text { Poor Rel. p. C. }\end{array}$ & $\begin{array}{c}(5) \\
Y r .{ }^{*} \text { Poor R. p. C. }\end{array}$ & $\begin{array}{c}\text { (6) } \\
\text { Riots/Year }\end{array}$ \\
\hline Poor Relief per Capita & & & $\begin{array}{c}-249.96^{* * *} \\
(60.67)\end{array}$ & & & $\begin{array}{c}-273.51^{* * *} \\
(64.90)\end{array}$ \\
\hline Year & $\begin{array}{c}0.00096^{* *} \\
(0.00047)\end{array}$ & $\begin{array}{l}1.895^{* *} \\
(0.855)\end{array}$ & & $\begin{array}{c}0.00101^{* *} \\
(0.00047)\end{array}$ & $\begin{array}{c}1.990^{* *} \\
(0.846)\end{array}$ & \\
\hline Year * Poor $\widehat{\text { Rel. per } C .}$ & & & $\begin{array}{l}0.135^{* * *} \\
(0.0328)\end{array}$ & & & $\begin{array}{l}0.148^{* * *} \\
(0.0351)\end{array}$ \\
\hline Black Death Impact & $\begin{array}{l}0.0172^{*} \\
(0.0032)\end{array}$ & $\begin{array}{c}31.48^{* * *} \\
(5.845)\end{array}$ & & $\begin{array}{c}0.0158^{* * *} \\
(0.00406)\end{array}$ & $\begin{array}{c}29.0^{* * *} \\
(7.44)\end{array}$ & \\
\hline Usable Land & $\begin{array}{c}-0.00238^{* *} \\
(.00062)\end{array}$ & $\begin{array}{c}-4.359^{* * *} \\
(1.129)\end{array}$ & & $\begin{array}{c}-0.00257^{* * *} \\
(0.00064)\end{array}$ & $\begin{array}{c}-4.70 * * * \\
(1.168)\end{array}$ & \\
\hline Observations & 230 & 230 & 230 & 226 & 226 & 226 \\
\hline R-squared & 0.436 & 0.435 & 0.286 & 0.444 & 0.443 & 0.339 \\
\hline K-P Wald F statistic & & 8.101 & & & 6.933 & \\
\hline Hansen J statistic & & .595 & p-val: .4403 & & .391 & p-val: .5317 \\
\hline A-R Wald F statistic & & 6.91 & p-val: .0002 & & 7.61 & p-val: .0001 \\
\hline S-W s statistic & & 16.58 & p-val: .0006 & & 17.11 & p-val: .0007 \\
\hline
\end{tabular}

OLS regression results reported in all columns. No fixed effects included in columns (1) and (4).

County fixed effects in columns (2), (3), (5) and (6) but not shown. Robust errors in parentheses.

$$
* * * \mathrm{p}<0.01, * * \mathrm{p}<0.05, * \mathrm{p}<0.1
$$


Appendix A. UK County-Level Panel Data Variable Definitions and Data Sources

- Food Riots: Food riots data for the years between 1650 and 1684, 1777 and 1783, 1785 and 1802 and 1804 and 1815 are from Charlesworth (1893) and those for 1686 and 1749 and 1751 to 1775 are from Bohstedt (2010).

Bohstedt, J. 2010. The Politics of Provisions : Food Riots, Moral Eonomy, and Market Transition in England, c. 1550-1850.

Charlesworth, A. 1983. An Atlas of Rural Protest in Britain, 1548-1900. (Philadelphia, PA: University of Pennsylvania Press).

- Poor Relief:

\begin{tabular}{|c|c|l|}
\hline Year & Date of Source & Source \\
\hline 1685 & 1797 & Eden, The State of the Poor, vol. 1, p. 230. \\
\hline 1750 & 1824 & $\begin{array}{l}\text { Report from the Select Committee on Poor Rate Returns. } \\
\text { 1824, vol. 2, Appendix C, p. 10. }\end{array}$ \\
\hline 1776 & 1804 & Report Abstract of Returns, 1804, p. 714. \\
\hline 1784 & 1804 & Report Abstract of Returns, 1804, p. 714. \\
\hline 1803 & 1804 & Report Abstract of Returns, 1804, p. 714. \\
\hline 1815 & 1817 & Appendix, Report of the Committee, 1817, p. 154. \\
\hline
\end{tabular}

Eden, F. M., Sir, 1797. The State Of The Poor; Or, An History Of The Labouring Classes In England, From The Conquest To The Present Period. Vols. I-III. London:

J. Davis

Parliamentary Papers. 1803-4. Returns Relative to the Expense and Maintenance of the Poor in England. Vol. XIII

Report from the Select Committee on Poor Rate Returns. 1824, Ordered by the House of Commons, printed on 15, June 1824. Great Britain.

Report from the Select Committee on the Poor Laws. 1817. Ordered by the House of Commons

- Wealth:

Buckatzsch, E.J. 1950. The Geographical Distribution of Wealth in England. 10861843: An Experimental Study of Certain Tax Assessment. The Economic History Review, ns, Vol. 3(2): 180-202, Table 1. 
- County Population Levels and Growth Rates:

\begin{tabular}{|l|l|}
\hline Year & Source \\
\hline 1650 & Extrapolated \\
\hline 1685 & Extrapolated \\
\hline 1700 & 1812 Abstract of the answers and returns, xxviii. \\
\hline 1750 & 1812 Abstract of the answers and returns, xxviii. \\
\hline 1776 & Extrapolated \\
\hline 1784 & Extrapolated \\
\hline 1803 & Population for 1801. 1812 Abstract of the answers and returns, xxviii.. \\
\hline 1811 & 1812 Abstract of the answers and returns, xxviii. \\
\hline & also in the Report of the Committee on Poor Relief, 1824, p. 11 Appendix D \\
\hline
\end{tabular}

- Market Dependency: Proportion of the population engaged in the non-agricultural sector in the period following that date. Official data on sectorial distribution is available only from 1801 and for the earlier period we use the share of nonagricultural parishes in a county as revealed by their marriage patterns.

\begin{tabular}{|c|l|l|}
\hline Year & Name & Source \\
\hline 1650 & Non-agricultural Population Estimates, 1650 & Kussmaul (1999); 1661-1740. \\
\hline 1685 & Non-agricultural Population Estimates, 1685 & Kussmaul (1999); 1661-1740. \\
\hline 1750 & Non-agricultural Population Estimates, 1750 & Kussmaul (1999); 1741-1820. \\
\hline 1776 & Non-agricultural Population Estimates, 1776 & Kussmaul (1999); 1741-1820. \\
\hline 1784 & Non-agricultural Population Estimates, 1784 & $\begin{array}{l}1802 \text { Abstract of the } \\
\text { answers and returns, p.451. }\end{array}$ \\
\hline 1803 & Non-agricultural Population Estimates, 1803 & $\begin{array}{l}1812 \text { Abstract of the } \\
\text { answers and returns, p.427. }\end{array}$ \\
\hline 1815 & Non-agricultural Population Estimates, 1815 & $\begin{array}{l}1821 \text { Abstract of the } \\
\text { answers and returns, p.427. }\end{array}$ \\
\hline
\end{tabular}

Kussmaul, A. 1989. A General View of the Rural Economy of England, 1538-1840. (Cambridge, UK: Cambridge University Press).

Abstract of the answers and returns made pursuant to an act, passed in the fortyfirst year of King George III. intituled "An act for taking an account of the population of Great Britain, and the increase or diminution thereof." [With "Observations on the Results of the Population Act,41 Geo.III." ] [1] Great Britain. [London, 1802.]

Abstract of the answers and returns made pursuant to an Act passed in the fiftyfirst year of His Majesty King George III, intituled, "An Act for taking an account of the population of Great Britain, and of the increase or diminution thereof" : preliminary observations, enumeration abstract, parish register abstract, 1811 / House of Commons. Great Britain. London : H.M.S.O., 1812 
Census of Great Britain, 1821, Abstract of the answers and returns made pursuant to an Act, passed in the first year of the reign of His Majesty King George IV, intituled, "An Act for taking an account of the population of Great Britain, and of the increase or diminution thereof". Preliminary observations. Enumeration abstract. Parish register abstract. London.

- Charlesworth Food Riots: The recorded numbers of food riots and protests by county, Charlesworth (1983, chapter 3).

Charlesworth, A. 1983. An Atlas of Rural Protest in Britain, 1548-1900, (ed.), (Philadelphia, PA: University of Pennsylvania Press).

- Charleswoth Land Protests: The recorded numbers of land protests by county, Charlesworth (1983, ch. 2).

Charlesworth, A. 1983. An Atlas of Rural Protest in Britain, 1548-1900, (ed.), (Philadelphia, PA: University of Pennsylvania Press).

- Charleswoth Militia Protests: The recorded numbers of clubmen uprisings and militia protests, Charlesworth (1983, ch. 5).

Charlesworth, A. 1983. An Atlas of Rural Protest in Britain, 1548-1900, (ed.), (Philadelphia, PA: University of Pennsylvania Press).

- Grain Prices: Average grain prices over the subsequent inter-poor relief data dates as in the riot data.

Clark, G. 2003. "The Price History of English Agriculture, 1209-1914," University of California, Davis.

- Distance to London: 
Marshall J. 1835. "Analysis and Compendium of Population Returns, Church Establishment, Parochial Assessments etc, 1801-1835" London: Sherwood. Statement showing the Geographical position of each County of England.

- Law enforcement: Years, 1776, 1784. 1803, 1815.

Marshall J. 1835. "Analysis and Compendium of Population Returns, Church Establishment, Parochial Assessments etc, 1801-1835" London: Sherwood. p. 38, Statement showing the amount of Parochial Expenditures.

- Black Death Impact: A time invariant, county-level control variable measuring the difference in the county population estimates between 1290 and 1379, thereby proxying for the impact of the Black Death plague on the counties.

Calculated from Broadberry, Stephen, Bruce M. S. Campbell, and Bas van Leeuwen. 2010. "English Medieval Population: Reconciling Time Series and Cross Sectional Evidence." WP. University of Warwick. Table 8. http://www2.warwick.ac.uk/fac /soc/economics/staff/academic/broadberry .

- Land use: Porter, George Richardson. 1836. The progress of the nation, in its various social and economical relations, from the beginning of the nineteenth century to the present time. London: C. Knight \& Co.

Section on ""A General Statement of the Territorial Surface of Great Britain, Ireland, and th adjacent Islands..."

- Region Codes: North (1), South (3) or Center (2). 